Article

\title{
Impact of the Energy Sector on the Quality of the Environment in the Opinion of Energy Consumers from Southeastern Poland
}

\author{
Krzysztof Kud $^{1, *(\mathbb{D})}$, Marian Woźniak ${ }^{2}$ (D) and Aleksandra Badora $^{3}(\mathbb{D}$ \\ 1 Department of Enterprise, Management and Eco-Innovation, The Faculty of Management, \\ Rzeszów University of Technology, 12 Powstańców Warszawy Street, 35-959 Rzeszów, Poland \\ 2 Department of Economics, The Faculty of Management, Rzeszów University of Technology, \\ 12 Powstańców Warszawy Street, 35-959 Rzeszów, Poland; mwozniak@prz.edu.pl \\ 3 Department of Agricultural and Environmental Chemistry, University of Life Sciences in Lublin, \\ 15 Akademicka Street, 20-950 Lublin, Poland; aleksandra.badora@up.lublin.pl \\ * Correspondence: kkud@prz.edu.pl; Tel.: +48-600-945-954
}

check for updates

Citation: Kud, K.; Woźniak, M.; Badora, A. Impact of the Energy Sector on the Quality of the Environment in the Opinion of Energy Consumers from Southeastern Poland. Energies 2021, 14, 5551. https://doi.org/10.3390/ en14175551

Academic Editors: Luigi Aldieri and Claudiu Albulescu

Received: 31 July 2021

Accepted: 3 September 2021

Published: 5 September 2021

Publisher's Note: MDPI stays neutral with regard to jurisdictional claims in published maps and institutional affiliations.

Copyright: (c) 2021 by the authors. Licensee MDPI, Basel, Switzerland. This article is an open access article distributed under the terms and conditions of the Creative Commons Attribution (CC BY) license (https:/ / creativecommons.org/licenses/by/ $4.0 /)$.

\begin{abstract}
Limiting $\mathrm{CO}_{2}$ emissions has been adopted as a contemporary challenge and introduced into numerous global and regional policies. The measures taken to reduce greenhouse gas emissions largely relate to the decarbonization of the economy. Changes in the Polish energy sector are a huge challenge because the energy mix is dominated by the energy derived from coal combustion. Decarbonizing the energy sector will require significant financial resources. Therefore, several questions arise: What is the social attitude to the planned changes? How do residents treat the issue of greenhouse gases? Do they perceive the relationship between energy production and the quality of the natural environment? What are their expectations regarding the transformation of the energy sector? The aim of this study was to identify the opinion of the inhabitants of southeastern Poland on changes in the energy sector and its impact on the quality of the natural environment. The study was conducted at the turn of 2020 and 2021. The survey was partial and carried out using the CAWI (Computer Assisted Web Interview) method; 1539 questionnaire forms were filled in and the sample was randomly selected. The study confirms the following research hypotheses: 1 . There is social support for the view that climate change is currently one of the greatest threats to modern civilization. 2. There is a social belief that the quality of the natural environment in southeastern Poland is good compared to other regions of Poland and Europe. 3. Increasing the share of energy based on renewable energy sources is socially expected. 4 . There is a social expectation of nuclear energy. It can therefore be concluded that the surveyed community accepts the direction of changes in the energy sector.
\end{abstract}

Keywords: energy sector; environmental quality; renewable energy sources (RES); nuclear energy; southeastern Poland

\section{Literature Review \\ 1.1. European Union (EU) Policy and Community Obligations}

The climate and energy policy of the European Union (EU) is long-term and aims to achieve climate neutrality by 2050. EU policy has a significant impact on changes in the Polish energy strategy [1]. In order to switch to low-emission energy, the EU is implementing its climate and energy goals for 2020 and 2030 [2]. These trends accelerate significantly and this is a challenge for energy transformations in Poland in the near future $[3,4]$.

The Paris Agreement was concluded at the "21st Conference of the Parties to the United Nations Framework Convention on Climate Change (COP21)" [5-7]. It was agreed at this conference that it was necessary to stop the increase in the global mean temperature and maintain it below $2{ }^{\circ} \mathrm{C}$. However, it should be ensured that it does not exceed $1.5^{\circ} \mathrm{C}$. During the Polish presidency of the EU, in December 2018, the Paris Agreement began 
to be implemented in Poland through the so-called "Katowice Climate Package" [8]. At that time, great emphasis was placed on making this transformation fair and in solidarity. "Clean Energy for All Europeans" is an EU package that shows the way to build a single energy market and achieve the EU's 2030 climate and energy goals [2,9]. Work on it ended in 2019 [4]. The Polish government actively influenced the shaping of the final version of the European model, which will determine the future of the Polish energy market $[3,10]$. A further revision of the key EU regulations relating to the energy sector is anticipated in the future. This applies in particular to the long-term vision of reducing greenhouse gas emissions by 2050 [1]. The European Green Lad from 2019 is an ambitious EU strategy striving for climate neutrality by 2050 [10,11]. Poland supported the European Green Lad, but tried to take into account the basic socioeconomic aspects that exist in our country $[3,12]$.

All global economies were hit by the coronavirus (COVID-19) pandemic in 2020 [13]. It highlighted the important role of the energy security of Poland and other European countries $[9,10]$. It is important that after a pandemic, investment decisions are made in the context of ecological and low-carbon economic recovery [6,7]. Both national protection tools and EU support will be undertaken in Poland [3,14]. Moreover, the manner of carrying out the transformation should take into account socially acceptable energy prices in order not to aggravate energy poverty [8,14].

At the heart of the European Energy Policy are various measures aimed at creating an integrated energy market and ensuring security of energy supplies and a stable energy sector $[10,13]$.

In line with the provisions made in the framework of the Energy Union of 2015 [9], the five most important goals of the EU's energy policy are (i) diversification of European energy sources, ensuring energy security through solidarity and cooperation between EU countries; (ii) ensuring the functioning of a fully integrated internal energy market, allowing energy to flow freely within the EU through appropriate infrastructure and without technical or regulatory barriers; (iii) improving energy efficiency and reducing energy import dependency, reducing emissions and stimulating job creation and economic growth; (iv) decarbonizing the economy and moving to a low-carbon economy in line with the Paris Agreement; and (v) promoting research in low carbon and clean energy technologies and giving priority to research and innovation to stimulate the energy transition and improve competitiveness [2]. An EU decision introduced changes to the energy efficiency and governance policy of the Energy Union in 2019 in the context of the United Kingdom's withdrawal from the EU [11]. The European Parliament has consistently expressed its strong support for a common energy policy that includes decarbonization, competitiveness, security, and sustainable development [1,4]. The European Parliament also supports the adoption of firmer commitments to meet the EU's own goals, highlighting the fact that the new energy policy must support the EU's greenhouse gas emissions reduction target and become climate neutral by $2050[5,15]$.

PEP2040 (Poland's Energy Policy until 2040) is our national contribution to the EU's climate and energy goals [14]. The energy policy of Poland adjusts our national economy to the EU regulatory conditions in accordance with national possibilities [1,6,14]. PEP2040 predicts that the low-emission energy transformation will initiate the modernization of the entire national economy, guarantee energy security, ensure a fair distribution of costs and protect the most vulnerable social groups $[8,16]$. The PEP2040 also includes an innovative approach to the environment and climate, which should be accepted by society $[17,18]$. The Polish energy transformation will be based on three pillars (Table 1) and on key strategic elements (Table 2), setting out the detailed goals of this transformation [14]. 
Table 1. Three pillars of the Polish energy transformation [14].

\begin{tabular}{|c|c|c|}
\hline $\begin{array}{c}\text { Pillar I } \\
\text { Fair Transformation }\end{array}$ & $\begin{array}{c}\text { Pillar II } \\
\text { Emission-Free Energy } \\
\text { System }\end{array}$ & $\begin{array}{c}\text { Pillar III } \\
\text { Good Quality Air }\end{array}$ \\
\hline Transformation of coal mines & Offshore wind & $\begin{array}{l}\text { Innovation of heat } \\
\text { engineering }\end{array}$ \\
\hline Reducing energy shortages & Nuclear energy & Electrification in transport \\
\hline RES *-related jobs & Energy from other sources & $\begin{array}{l}\text { Development of the "Dom z } \\
\text { Klimatem" program }\end{array}$ \\
\hline
\end{tabular}

Table 2. Key elements of PEP2040 [17,18].

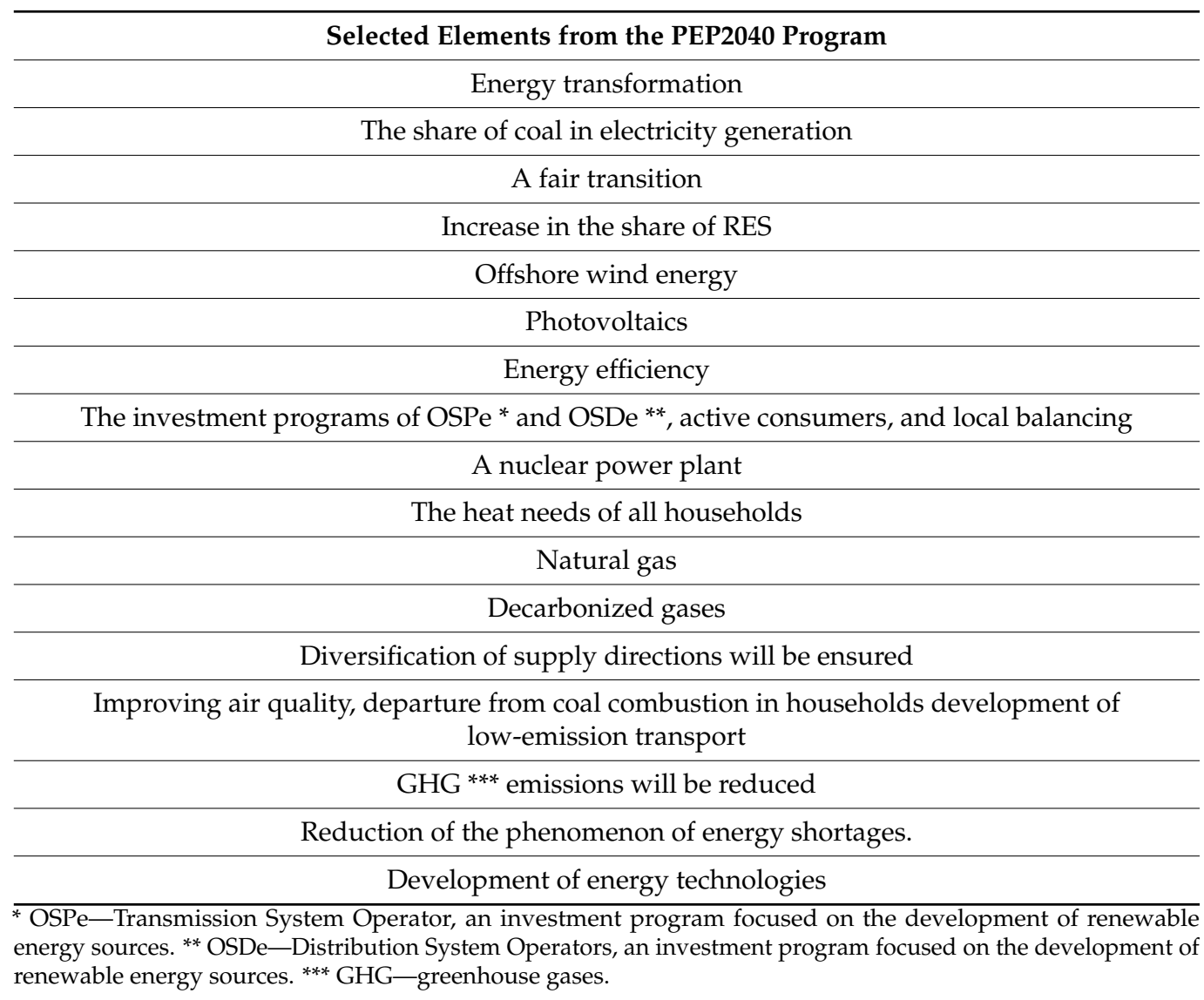

The Polish Energy Transition will therefore be fair and will take into account all social groups. It will be initiated from the bottom up and will be focused on modernization and innovation $[14,16]$. It will also stimulate economic development, efficiency, and competitiveness $[3,18]$. Table 2 shows a more detailed description of the goals contained in the three pillars.

Therefore, Poland's Energy Policy is based not only on security and ensuring the competitiveness of the economy, but also on reducing the environmental impact of the energy sector and on the optimal use of its own energy resources $[14,16,18]$.

\subsection{The Impact of Power Engineering on the Natural Environment}

A resolution adopted by the General Assembly (UN) on 25 September 2015 “Transforming Our World: The 2030 Agenda for Sustainable Development" [19] sets out 17 sustainable development goals and 169 related tasks to be achieved by 2030. These goals concern five areas of the so-called $5 \times$ P: People, Planet, Prosperity, Peace, and Partnership [20]. The resolution was signed by all 193 member states of the United Nations, 
which undertook to monitor the achievement of goals and tasks through appropriate indicators [21,22]. In Poland, these indicators are dealt with by the Central Statistical Office [23]. When analyzing the sustainable development goals, special attention should be paid to two, namely goal 7: "Ensure access to stable, sustainable, and modern energy at affordable prices for all", and goal 13: "Take urgent measures to combat climate change and their effects" [19]. The implementation of these goals, together with the related tasks, is to significantly contribute to accelerating the reduction of global greenhouse gas emissions by increasing the share of renewable energy sources and by increasing the global efficiency of energy consumption [5]. It is also to contribute to undertaking adaptation measures to the progressive negative effects of climate change $[11,17,24]$.

Achieving a deep reduction of greenhouse gases or even climate neutrality by 2050 will require qualitative changes in Polish Domestic Policy, going far beyond the scenarios considered in the national public debate [14], including: ensuring even twice as much electricity supply with almost complete elimination of emissions from power engineering; complete elimination of fossil fuel heating in buildings; dominating the energy mix in transport by alternatives to fossil fuels (electromobility, biofuels, synthetic fuels, or hydrogen); replacement of traditional technologies in heavy industry with zero-emission alternatives and the widespread implementation of the principles of the circular economy; large and simultaneously sustainable increase in the supply of biomass for energy purposes [17]. The main objective of the Polish Energy Policy is to develop the potential of the environment for the benefit of citizens and entrepreneurs [18]. The specific objectives will take into account the most important trends in the field of the environment, in a way that allows for harmonizing issues related to environmental protection with economic and social needs [12]. The topic of energy is included in the directions of interventions regarding the elimination of air pollutant emission sources [3]. It specifies the directions of activities that will receive support, such as investments related to increasing the share of renewable energy [14], modernization of CHP systems in order to reduce pollutant emissions [25], development of low-emission transport [26], reduction of energy losses related to its transmission, and the development of energy clusters $[14,18]$ and transformation of municipalities into energy self-sufficient communities [12,27].

Various branches of the energy sector affect various elements of the environment in a variety of ways, including for people, animals, plants, water, air, landscape, climate, and natural resources (Table 3) [18].

Table 3. Impact on selected elements of the environment on some alternative branches of the energy sector [18].

\begin{tabular}{|c|c|}
\hline Elements of the Environment & Influence \\
\hline \multicolumn{2}{|r|}{ Construction of nuclear power plants } \\
\hline Air & $\begin{array}{l}\text { positive: reducing air pollutant emissions from other energy producing sources. negative: } \\
\text { emissions of air pollutants during construction. }\end{array}$ \\
\hline Water & $\begin{array}{c}\text { negative: during construction, impacts on surface and groundwater may be associated with } \\
\text { changes in water relations. } \\
\text { negative: during operation, due to the intake and discharge of large amounts of water for the } \\
\text { cooling system. }\end{array}$ \\
\hline People & $\begin{array}{l}\text { positive: by partially replacing conventional energy, it indirectly reduces the emission of } \\
\text { pollutants into the air, and therefore reduces the negative impact on human health. negative: } \\
\text { an (insignificant) increase in the level of ionizing radiation in the vicinity of nuclear power } \\
\text { plants, the risk of accidents, and the associated risk of releasing larger amounts of radioactive } \\
\text { substances, generation of radioactive waste, emission of noise, and air pollution during } \\
\text { construction work. Negative psychological impact. }\end{array}$ \\
\hline Animals & $\begin{array}{l}\text { negative: land taking, impacts during construction; indirectly positive impact by reducing the } \\
\text { emission of atmospheric pollutants from the energy sector. }\end{array}$ \\
\hline Plants & $\begin{array}{l}\text { negative: land taking, impacts during construction; indirectly positive impact by reducing the } \\
\text { emission of atmospheric pollutants from the energy sector. }\end{array}$ \\
\hline
\end{tabular}


Table 3. Cont.

\begin{tabular}{cr}
\hline Elements of the Environment & Influence \\
\hline Climate & $\begin{array}{c}\text { positive: reduction of greenhouse gas emissions from conventional energy. } \\
\text { Landscape }\end{array}$ \\
Natural resources & $\begin{array}{r}\text { negative: disturbing the landscape with "foreign" elements by building new cubature objects. } \\
\text { positive: reducing the use of nonrenewable resources (fossil fuels) for energy production. } \\
\text { negative: using uranium, thorium as fuel for a nuclear power plant, and rock raw materials at } \\
\text { the construction stage of the investment. }\end{array}$ \\
\hline
\end{tabular}

\section{RES-photovoltaics and solar collectors}

positive: indirect-the use of solar energy will reduce the consumption of fossil fuels and

Air

$$
\text { also thermal comfort. }
$$

related air pollutant emissions; this will improve air quality, and in the case of solar panels

negative: emissions of air pollutants during the construction of photovoltaic farms and solar panels. no impact

Water

People

Animals

Plants

Climate

Landscape

Natural resources

Air

Water

People

Animals

Plants

Climate

Landscape

Natural resources

positive: improved air quality will have positive health effects; moreover, when used for heating, it will improve the comfort of the residents; it can improve energy security. possible negative consequences as a result of the occupation of land for solar farms and solar panels, along with electricity and heat output infrastructure; impacts will depend on the location.

slight negative during construction; positive due to impact on air quality.

negative: land taking and limitation of biologically active area; deforestation of forests and trees.

slight negative under construction; positive due to impact on air quality.

positive: reducing greenhouse gas emissions by replacing fossil energy with renewable energy sources.

negative: disturbance of the landscape with "foreign" elements.

positive: reduced use of fossil energy resources.

negative: due to the consumption of raw materials for the production of devices.

RES-water and energy resources

negative: emission of fumes and dust during construction works; the negative impact is short-term and related to the implementation of the investment, i.e., carrying out construction work.

positive: clean energy production.

negative: during the implementation of water structures, including hydrotechnical devices, it may adversely affect the quality of water and ecosystem function below the project location;

in contrast, during operation, various types of impacts on the aquatic ecosystem, both negative and in selected aspects, are possible.

positive: more serious threats and significant negative impacts are related to the construction and operation of large dam reservoirs, which are associated with significant hydrological changes, deterioration of water quality in reservoirs as a result of sedimentation of pollutants, and disturbances in ecosystem function.

positive: clean energy production, increasing retention, delaying water runoff, and creation of recreational areas.

negative: noise and exhaust emissions during work; changes in the organization of road traffic related to the implementation of the investment. The negative impact is short-term and

is related to the implementation of the investment, i.e., carrying out construction works.

Long-term, illusory sense of security, technical buildings in river valleys increase below the dams and flood losses accumulate.

negative: a change in water relations may result in an imbalance of ecosystems, causing animal migration and / or increasing fish mortality; in addition, ecological corridors may be interrupted-animals may be disturbed, frightened, and leave during the construction stage. negative: interference with water conditions and taking the land for investment affect the destruction of natural habitats (in particular those dependent on water).

positive impact on reducing greenhouse gas emissions and adapting to climate change. negative: possible methane emissions from dam reservoirs aggravate this global warming. negative: disturbance of the landscape with "foreign" elements in space. positive: creating reservoirs.

negative: consumption of rock raw materials during the construction phase. positive: reducing the consumption of energy resources. 
Table 3 shows that the planned development of both renewable energy sources and nuclear energy in Poland has an impact on the natural environment $[14,17,24]$. This impact can be both positive and negative, and short- and long-term. In contrast, it is believed that the abovementioned energy sources are mostly low-emission or zero-emission, and thus fit into the zero-emission economy of the future, not only in Poland, but also in the EU and worldwide $[14,15,24]$.

\subsection{Climate Changes and Power Engineering}

According to scientists from around the world, the phenomena occurring on Earth today are very disturbing because the highest temperatures and the greatest concentration of $\mathrm{CO}_{2}$ have been observed in the last twenty years, ever since these parameters were measured [28]. According to the data of the World Meteorological Organization (WMO) [29], the years 2010-2019 were the hottest years in the entire history of the Earth, and 2019 was one of the top three warmest years in the entire history of measurements [28]. The data presented by WMO [29] therefore show that "our planet and life on Earth are on the brink", and climate change causes a much more frequent occurrence of violent weather phenomena, which in turn also affects the existence of the world's population [30]. However, one should remember the bilateral dependence, as climate change affects the population, but also the population can contribute to this change by promoting activities related to the emission of greenhouse gases [31,32].

The results of the report of the International Panel on Climate Change (IPCC) [33] show that in order to avoid exceeding the limit of the temperature increase by $1.5^{\circ} \mathrm{C}$, only technological changes are not enough, as achieving this goal depends to a large extent on changing lifestyle to focus on reducing energy consumption [31]. Scientists claim that humanity should comply with the policy of energy efficiency in the coming years because the fate of the Earth and the planet's inhabitants will depend on it [34]. Climate change, caused by the increase in global temperature, will be felt worldwide, regardless of where they live, and it will also affect Polish residents [35]. According to the members of the International Panel on Climate Change, an increase in the mean global temperature by $2{ }^{\circ} \mathrm{C}$ will cause the Earth to face far more frequent weather anomalies, such as storms, floods, droughts, storms, fires, and frosts [29,30].

The report [30] underlines that in 2019, 409 natural disasters were recorded globally, largely as a result of climate change. These disasters resulted in losses amounting to 232 billion USD, of which 71 billion related to the payment of claims. Just five of the costliest flood disasters in the US, China, India, and Iran cost more than 53 billion USD in direct economic impact. In Poland, the droughts in 2019 burdened the economy with around 1 billion USD and largely translated into a 5\% increase in food prices [36]. Additionally, it is emphasized that the occurrence of drought each year may cause a snowball effect, accumulating negative consequences and leading to, for example, soil desertification [28,35]. In contrast, it is a fact that energy is necessary in the process of creating wealth in industry and commerce, and also to achieve a proper quality of life in society [37]. Energy consumption is also a significant source of greenhouse gases produced by humanity, as about two-thirds of the global greenhouse gas emissions are the result of burning fossil fuels for the production of heat and electricity, together with transport and industry [15,31].

There is a clear relationship between energy and welfare, as measured by GDP per capita and $\mathrm{CO}_{2}$ emissions at the same time [37]. The richer the society, the greater the consumption of energy; therefore, the thesis can be presented that with the economic development of countries, higher energy consumption and, at the same time, higher $\mathrm{CO}_{2}$ emissions per capita take place. An example is the USA, where GDP per capita is over 63,000 USD [38]. In Poland, about $10 \mathrm{~kg}$ of coal, $3 \mathrm{~L}$ of oil, and $1 \mathrm{~m}^{3}$ of gas are consumed per person each day, and owing to fossil fuels the way of life of the society has changed dramatically. In 2019, Poland, with a GDP per capita of USD 15,274, was 45th in the world, and the overall $\mathrm{CO}_{2}$ emissions per capita were $35 \%$ lower compared to 1980 , which 
resulted in 8.5 tons of $\mathrm{CO}_{2}$-equivalent greenhouse gases and ranked the country 36th in the world [35].

In the period 1999-2019, world GDP increased by nearly 70\%, which resulted in an increase in energy consumption by about $40 \%$ and by the same amount of $\mathrm{CO}_{2}$ emissions from fossil fuel combustion [33]. It should be noted that in the 2019-2020 period, developed economies saw an average decrease of $10 \%$ in annual emissions, while in emerging and developing economies the decrease was only $4 \%$ [32]. The largest decrease was recorded in the USA (by nearly $50 \%$ ) and in the European Union generally over $25 \%$, while China saw an increase in emissions (by nearly $8 \%$ ) [39,40].

In the European Union, in the years 1990-2019, the emission of the main greenhouse gases (Table 4) reached a total value of 5630 million tons, of which $\mathrm{CO}_{2}$ emissions were the greatest (82.5\%), followed by $\mathrm{CH}_{4}$ and $\mathrm{N}_{2} \mathrm{O}$ [32]. Over the analyzed period, a downward trend in the amount of emitted gases was observed. Generally, in 2019 it decreased by $29.1 \%$ in relation to 1990 . The downward trend concerned practically all greenhouse gases except HFCs (hydrofluorocarbons), where an upward trend was recorded [33].

Table 4. Overview of emissions and removals of the EU's main greenhouse gases 1990-2019 in million tons of $\mathrm{CO}_{2}$ [32].

\begin{tabular}{ccccccccc}
\hline Specification & $\mathbf{1 9 9 0}$ & $\mathbf{2 0 0 0}$ & $\mathbf{2 0 1 0}$ & $\mathbf{2 0 1 5}$ & $\mathbf{2 0 1 6}$ & $\mathbf{2 0 1 7}$ & $\mathbf{2 0 1 8}$ & $\mathbf{2 0 1 9}$ \\
\hline $\begin{array}{c}\mathrm{CO}_{2} \text { emissions } \\
\left(\text { with LULUCF }^{*} \text { ) }\right.\end{array}$ & 4494 & 4185 & 3956 & 3530 & 3513 & 3526 & 3446 & 3296 \\
$\mathrm{CH}_{4}$ & 729 & 612 & 496 & 464 & 458 & 460 & 451 \\
$\mathrm{~N}_{2} \mathrm{O}$ & 407 & 325 & 259 & 257 & 256 & 261 & 257 & 255 \\
$\mathrm{HFCs}^{* *}$ & 29 & 53 & 99 & 106 & 106 & 105 & 94 \\
\hline Total & 5630 & 5122 & 4711 & 4251 & 4227 & 4247 & 4154 \\
$($ with LULUCF
\end{tabular}

* LULUCF—(Land Use, Land Use Change, and Forestry). ${ }^{* *}$ HFCs—(hydrofluorocarbons).

When interpreting the main sources of greenhouse gas emissions in the EU in 1990-2019 (Table 5), it can definitely be stated that it is the energy sector to the greatest extent (77\%), followed by agriculture and industry [15,32]. As in the case of general issuance, the main issuer sectors also recorded a downward trend in the period under review [33,39], which can also be seen in most countries (Table 6) [32].

Table 5. Overview of EU greenhouse gas emissions (million tons of $\mathrm{CO}_{2}$ equivalent) in terms of main sources and sinks in 1990-2019 [32].

\begin{tabular}{ccccccccc}
\hline Specification & $\mathbf{1 9 9 0}$ & $\mathbf{2 0 0 0}$ & $\mathbf{2 0 1 0}$ & $\mathbf{2 0 1 5}$ & $\mathbf{2 0 1 6}$ & $\mathbf{2 0 1 7}$ & $\mathbf{2 0 1 8}$ & $\mathbf{2 0 1 9}$ \\
\hline Energy & 4358 & 4012 & 3801 & 3376 & 3357 & 3361 & 3282 & 3132 \\
Industrial Process & 530 & 463 & 397 & 381 & 381 & 390 & 380 & 370 \\
Agriculture & 537 & 459 & 423 & 433 & 434 & 437 & 432 & 429 \\
Waste & 240 & 228 & 167 & 142 & 139 & 138 & 136 & 135 \\
\hline Total (with & \multirow{2}{*}{5669} & 5166 & 4790 & 4335 & \multirow{2}{*}{4312} & 4327 & 4233 \\
LULUCF ${ }^{*}$ ) & & & & & & 4067 \\
\hline
\end{tabular}

* LULUCF-( Land Use, Land Use Change, and Forestry).

In the case of the energy sector, Large Combustion Plants (LCPs) deserve special attention, which vary in size from $50 \mathrm{MWt}$ (megawatts of thermal power) to even over 2000 $\mathrm{MWt}$, the very large ones account for $21 \%$ of the LCP and generate $70 \%$ of installed power. In the EU, they account for around $40 \%$ of the electricity production capacity and depend highly on fossil fuels, producing a significant amount of emissions of air, water, and land pollutants [31,37]. In this situation, many countries are wondering what direction should be taken to develop an energy policy in order to meet the growing energy needs and, at the same time, to reduce $\mathrm{CO}_{2}$ emissions [6,15]. Scientists say that getting out of the situation is definitely not linked to the use of carbon [41]. However, is politics heading towards 
the end of the coal age? It definitely does not indicate this, as coal remains a significant fuel $[14,31]$. However, international environmental organizations in the Boom and Bust report $[33,42]$ estimate that the number of new coal-fired power plants in 2017 decreased by $29 \%$ compared to 2016 , and by as much as $73 \%$ compared to 2015 .

Table 6. Energy industry: contribution of the largest and smallest emitters to $\mathrm{CO}_{2}$ and $\mathrm{N}_{2} \mathrm{O}$ emissions in EU countries [32].

\begin{tabular}{|c|c|c|c|c|c|c|}
\hline Member State & $\begin{array}{c}\mathrm{GHG}^{*} \\
\text { Emissions in } \\
1990 \\
\left(\mathbf{k t}^{* *} \mathrm{CO}_{2}\right. \\
\text { Equivalents) }\end{array}$ & $\begin{array}{c}\text { GHG Emissions } \\
\text { in } 2019 \\
\text { (kt } \mathrm{CO}_{2} \\
\text { Equivalents) }\end{array}$ & $\begin{array}{c}\mathrm{CO}_{2} \text { Emissions } \\
\text { in } 1990 \\
(\mathrm{kt})\end{array}$ & $\begin{array}{c}\mathrm{CO}_{2} \text { Emissions } \\
\text { in } 2019 \\
(\mathbf{k t})\end{array}$ & $\begin{array}{c}\mathrm{N}_{2} \mathrm{O} \text { Emissions } \\
\text { in } 1990 \\
\text { (kt } \mathrm{CO}_{2} \\
\text { Equivalents) }\end{array}$ & $\begin{array}{c}\mathrm{N}_{2} \mathrm{O} \text { Emissions } \\
\text { in } 2019 \\
\text { (kt } \mathrm{CO}_{2} \\
\text { Equivalents) }\end{array}$ \\
\hline \multicolumn{7}{|c|}{ Largest issuers } \\
\hline Germany & 427,353 & 249,696 & 423,906 & 244,822 & 3167 & 2073 \\
\hline $\begin{array}{l}\text { United Kingdom } \\
\text { (UK) }\end{array}$ & 236,325 & 86,521 & 234,721 & 85,404 & 1399 & 728 \\
\hline France & 66,350 & 38,212 & 65,835 & 37,897 & 448 & 268 \\
\hline Italy & 137,646 & 91,797 & 136,941 & 91,312 & 477 & 362 \\
\hline POLAND & 235,395 & 150,707 & 234,294 & 149,912 & 1018 & 691 \\
\hline \multicolumn{7}{|c|}{ Smallest issuers } \\
\hline Malta & 1766 & 740 & 1759 & 739 & 6 & 0 \\
\hline Cyprus & 1767 & 3293 & 1761 & 3282 & 4 & 8 \\
\hline EU $27+U K$ & 167,4802 & 986,865 & $1,665,064$ & 975,763 & 8543 & 6780 \\
\hline
\end{tabular}

* GHG-(greenhouse gases). ${ }^{* *} \mathrm{kt}$-kilotons.

The aim of this study was to identify the opinion of the inhabitants of southeastern Poland on changes in the energy sector and its impact on the quality of the natural environment. The answers to the following questions were sought: (i) What is the social attitude toward the planned changes? (ii) How do citizens treat greenhouse gases and climate change? (iii) Do they see the link between energy production and environmental quality? (iv) What are their expectations regarding the transformation of the energy sector?

\section{The Scope and Methodology of Research}

Youth education plays an important social role by shaping specific, desired attitudes [43]. Identification of the perception of the issue of the quality of natural environment may provide knowledge concerning the information gap in the topic studied. The study addressed to young people was based on the assumption that, first, since EU regulations focus on reducing $\mathrm{CO}_{2}$ emissions and stopping climate change [24], it is worth knowing the opinion of young people regarding the perception of these changes and the possibility of stopping them. Second, since the energy sector has an impact on the natural environment [44], how do young people perceive the state of this environment on a local, national and global scale. Third, an attempt was made to identify the expectations of young people regarding the directions of state activities that should be undertaken in the field of energy management.

Broadly understood society (demos) in a democratic system basically determines the shape of the law, and thus the economy [45]. Determining the views of adult energy consumers can be used to design changes in the energy sector or to plan social education [46]. Adults, as consumers of electricity in various forms, are an important element in shaping the relationship between the economy and the natural environment [47]. The survey was to answer the following questions: Do the respondents associate the functioning of the energy sector with the issues of caring for the natural environment? How do they perceive care for the environment and what solutions do they expect from the energy sector? Is their environmental attitude related to the perception of the energy sector?

The study was conducted from October 2020 to February 2021. In October 2020, adolescents under the age of 18 were tested. In February 2021, the survey was conducted among adults. A different tool was constructed to study school youth $(n=535)$ by adjusting the content of the questions to the intellectual level of adolescents, and a separate tool 
was created for adults $(n=1004)$. The survey was partial; it was carried out using the CAWI (Computer Assisted Web Interview) method; a total of 1539 reliably completed survey forms were collected. The research was not probabilistic; the selection of the sample was random. At the beginning, access to the questionnaire was given to several dozen people who met the condition of residence in the research area. These people represented various social groups: school youth, workers in the manufacturing sector, farmers, officials, students, etc. Then, these people invited others to take part in the study, meeting the criteria of age and place of residence in southeast Poland. The analysis and inference were carried out separately for both groups of respondents. The inference applied only to the studied group since the selection of the sample was random. In the analyzed sample, similar to the population inhabiting the research area, there was a certain numerical predominance of women. In terms of age, the respondents belonged to the largest age group in the surveyed voivodships [23]; however, the sample was not representative and the results refer to the surveyed group of people. The research area is characterized by high quality of the natural environment and significant forest cover (forest cover in \% in 2018 in Poland was 29.6, while in Podkarpackie Voivodeship 38.3\% and in Lubelskie Voivodeship 23.4\%) [48], high tourist potential [49], and a significant number of farms.

During the identification of attitudes and perceptions of the issues discussed in this paper, questionnaires were created containing a number of thesis formulations assessed by the respondents in terms of compliance with their beliefs. A bipolar, five-point Likert scale was used for the assessment [50]. On the scale, the value of 1 meant definitely not; 2-probably not; 3-neither yes nor no; 4-rather yes; 5-definitely yes. Statistical analyses were performed in the Statistica program..

. In the research material collected, basic descriptive statistics were calculated and the structure of assessments of diagnostic theses was analyzed [51]. Due to the selection of the sample, the research is the basis for further research and should not be generalized to the entire population of southeastern Poland.

\section{Research Results}

In the part of the study addressed to adolescents, $60.9 \%$ were women and $39.1 \%$ were men. Most of the surveyed people in this group (59.6\%) lived in cities, while $40.4 \%$ lived in the countryside.

In the part of the research diagnosing the perception of climate change and the quality of the natural environment by adolescents, the structure of assessments of formulated theses was calculated; the results are presented in Figure 1. Formulations 1 to 4 contained theses relating to the scale of the problem related to global warming. The vast majority $(74.2 \%)$ of respondents perceived global warming as one of the greatest problems of mankind. The thesis downplaying this problem was contradicted by $90.7 \%$ of the respondents (Figure 1). Theses 5-8 contained references to climate change, its specificity, and the possibilities of stopping the changes. More than half of the respondents (57.2\%) believed that climate change could be stopped. A similar percentage of respondents did not support the thesis that climate change is a tool of economic struggle. In contrast, $86.2 \%$ of respondents claimed that climate change is a consequence of human activity. The data presented show that young people were sensitive to the problem of global warming-they saw the role of humans in causing climate change and hoped that it could be stopped through human efforts.

In the part of the study relating to the perception of the natural environment, it is worth emphasizing that adolescents had the highest concerns about the state of the natural environment in a global perspective. In this case, $85.4 \%$ of the respondents were concerned about the condition of the Earth's natural environment (Figure 1). In the national perspective, the concerns were lower by $60.0 \%$, and in the perspective of the southeastern Poland region, the quality of the environment worried only $27.5 \%$ of the respondents. These results may indicate a high sensitivity to global problems, which are presented, inter alia, in the curricula. 
1. Global warming is currently one of the greatest threats to modern civilization.

2. Global warming is a threat, but it is one of many dangerous phenomena.

3. Global warming does not pose a particularly significant threat.

4. Global warming is not a dangerous phenomenon at all.

5. Climate change on Earth is unstoppable.

6. Climate change on Earth is mainly the business of certain earning groups by arousing fear or guilt.

7. Climate change on Earth is a natural phenomenon.

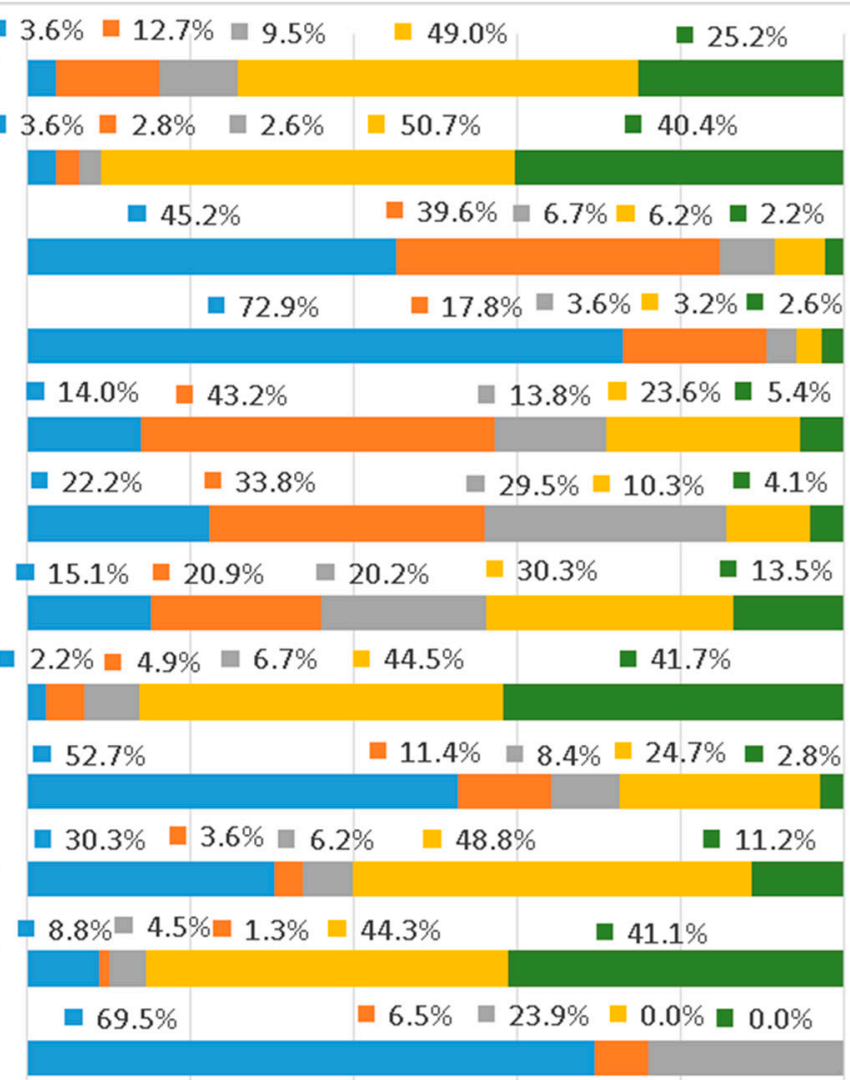

12. Can your actions contribute to the improvement of the condition of the environment in the Podkarpackie...

Definitely not $\quad$ Probably no $\quad$ Neither no, nor so $\quad$ Probably yes $\quad$ Definitely yes

Figure 1. The structure of assessments of theses diagnosing the perception of global warming, climate change, and the quality of the natural environment by young adolescents.

Figure 2 presents the structure of assessments of theses diagnosing the perception of the directions of energy policy development by adolescents and the expected directions of state support. According to the vast majority of respondents, special attention should be focused on measures aimed at improving energy efficiency and reducing energy consumption $(93.1 \%)$. Similar support $(94.2 \%)$ was obtained by the thesis postulating the development of the energy sector using renewable energy sources. Young people did not support the development of energy based on gas and crude oil, especially the energy of hard coal and lignite. In contrast, $46.2 \%$ of the respondents supported nuclear energy.

Regarding the directions of state support in the area of energy management, the respondents primarily expected the development of energy using renewable energy sources $(95.9 \%)$, energy-saving construction $(83.4 \%)$, and high energy efficiency of manufactured devices $(83.2 \%)$. The large support for the theses relating to the need to conserve energy and improve energy efficiency proves the high environmental awareness of the respondents (Table 6).

In order to learn about the perception of the benefits and disadvantages of energy production from renewable sources by respondents, a number of diagnostic theses were formulated, and the structure of their assessments is presented in Figure 3. Among the advantages of renewable energy, the improvement in air quality and the positive impact on health protection were generally most appreciated. Among the disadvantages of renewable energy, the respondents emphasized the high costs of renewable energy sources. Concerning other suggested drawbacks, the ratings were mixed. It should be emphasized, however, that there were the fewest assessments indicating a firm belief in a defect. This 
means that in the group studied, the general perception of renewable energy sources was positive.

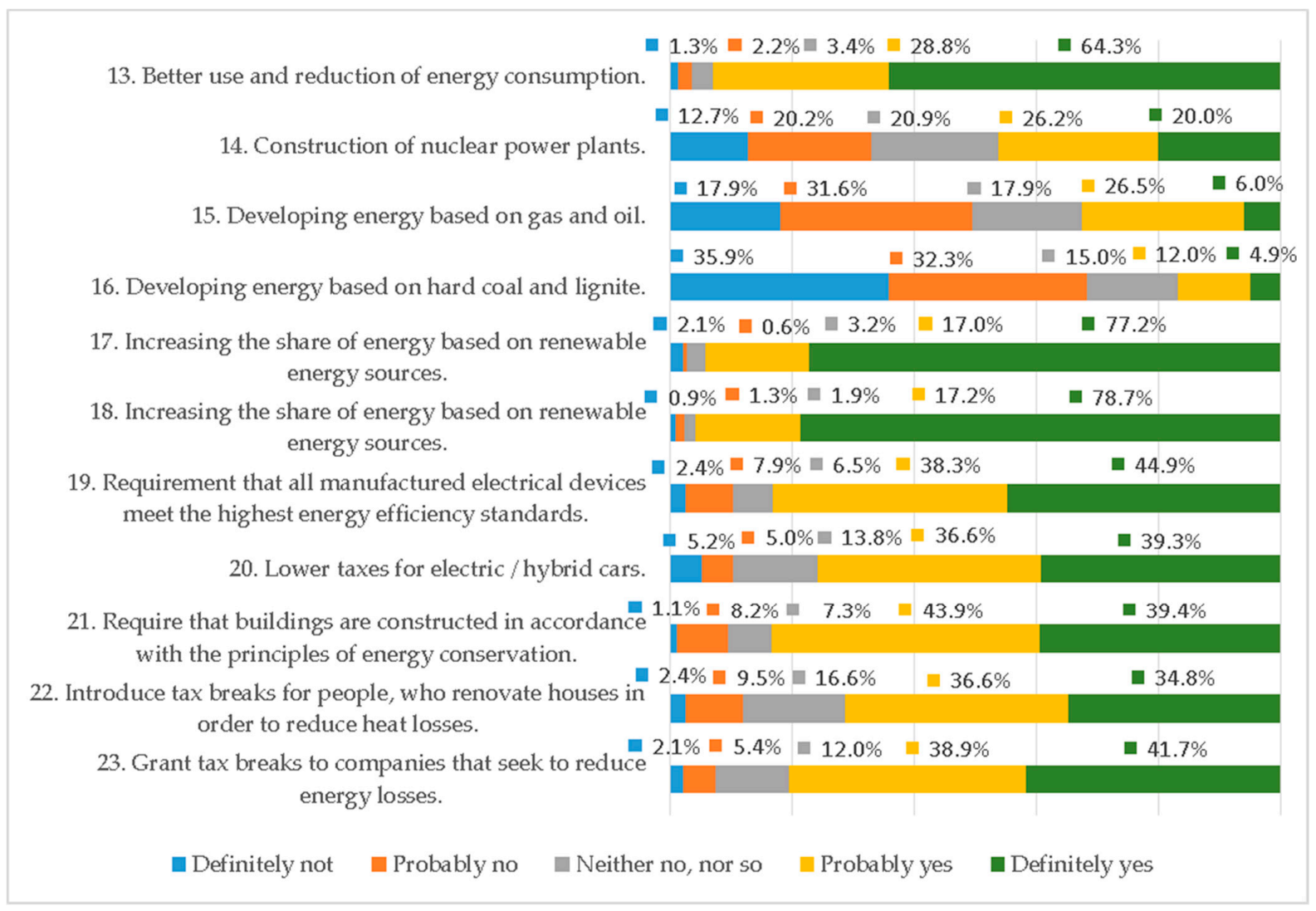

Figure 2. The structure of assessments of theses diagnosing the perception by adolescents of the directions of energy policy development and directions of state support.

In this research, an important issue was the perception of the quality of the natural environment by young people in the context of opinions on the benefits of producing energy from renewable sources. The calculated mean scores for theses relating to these issues are shown in Figure 4.

The differences between young people's concerns about the state of the environment depending on the perspective of perception were significant. The respondents had the greatest concerns about the state of the environment in the global perspective and the lowest in the local perspective. It is worth emphasizing that the surveyed adolescents assessed the possibility of personal influence on the quality of the natural environment as low (thesis 12). It seems justified to include in the curricula the role of individuals in shaping the quality of the natural environment.

The opinion on the benefits of energy production from renewable sources was positive, as evidenced by the high average scores, from 24 to 28 . The surveyed youth especially counted on the improvement of air quality and a positive impact on the quality of health.

In the part of the survey addressed to adults, the age of the respondents ranged from 18 to 77 years. Geometric mean was $S G=25.96$, median age (middle value) $\mathrm{Me}=23$ years, lower quartile being the limit of $25 \%$ of observations, Q1 $=21$ years, and the upper quartile, indicating the limit of $75 \%$ of observations, $Q 3=30$ years, modal, i.e., the most common value was 22 years. Most of the respondents were women, they constituted $57.5 \%$ of the respondents, and men accounted for $42.5 \%$. The place of residence of the respondents is shown in Figure 5. In the group studied, $52 \%$ of the respondents lived in the countryside, and $15.7 \%$ lived in a city with more than 100,000 residents. 


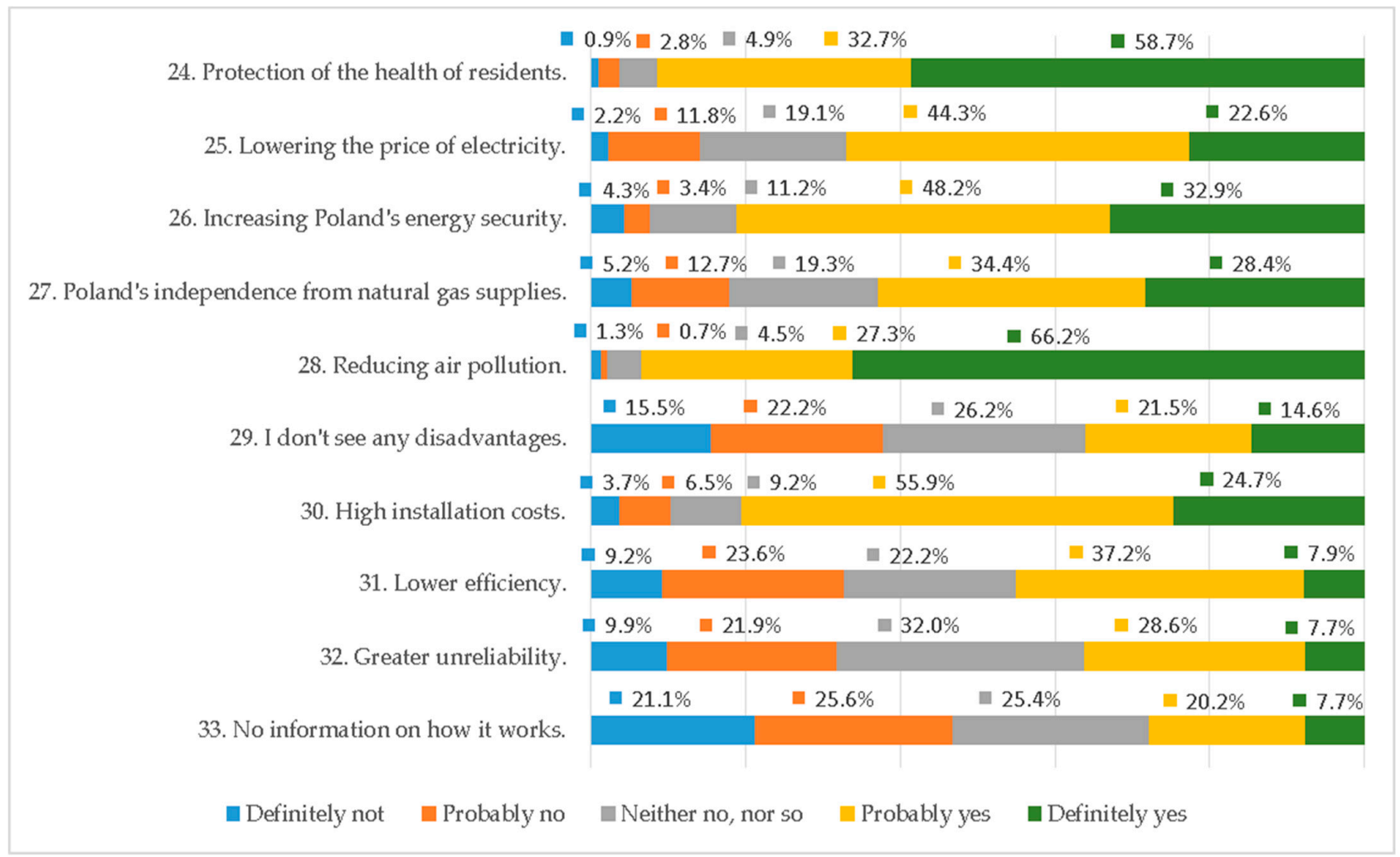

Figure 3. The structure of assessments of theses diagnosing the perception of advantages and disadvantages of energy production from renewable sources by adolescents.

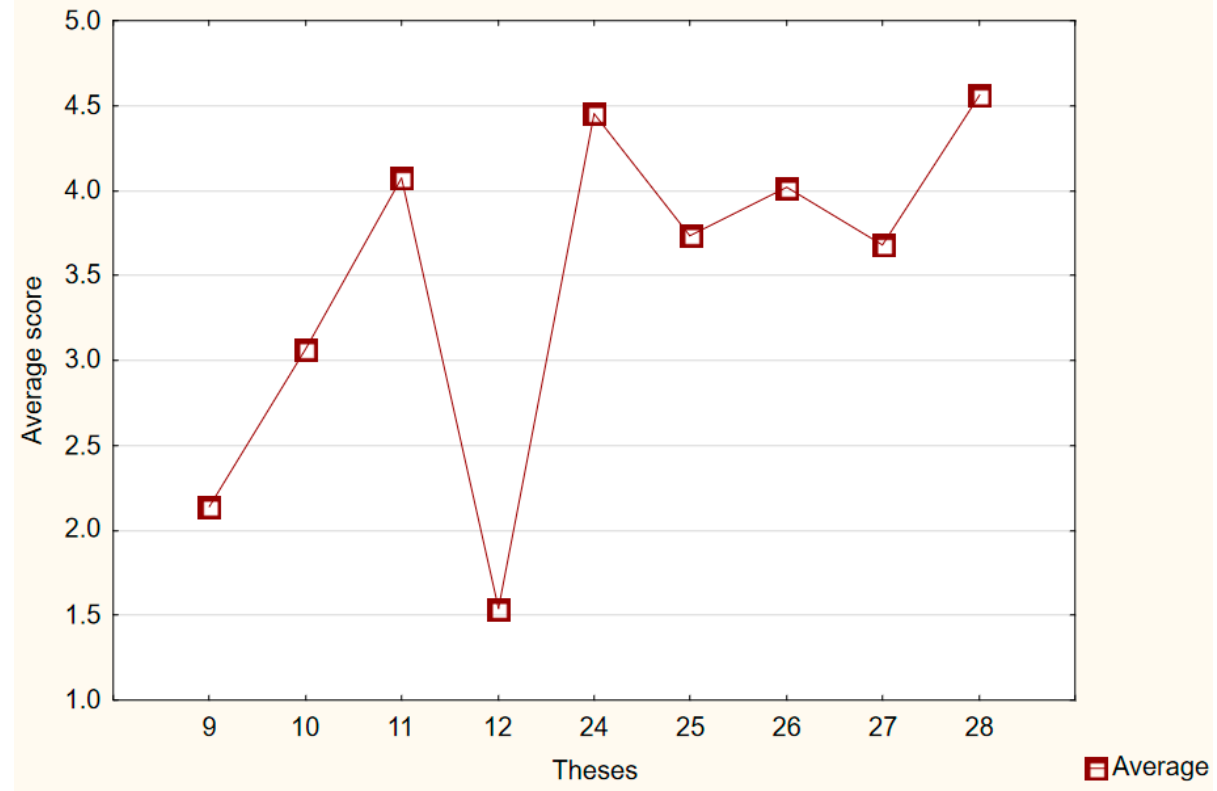

9. The current state of the natural environment is a cause of global concern and local concern in southeastern Poland; 10. The current state of the natural environment is a cause of global concern and concern in Poland; 11. The current state of the environment is a cause of concern and anxiety on Earth; 12. Can your actions contribute to the improvement of the condition of the environment in the Podkarpackie Province? 24. Protection of residents "health"; 25. Lowering the price of electricity; 26. Increasing Poland's energy security; 27. Poland's independence from natural gas supplies; 28. Reduction of air pollution.

Figure 4. Average ratings relating to the quality of the environment and the benefits of energy production from renewable sources. 


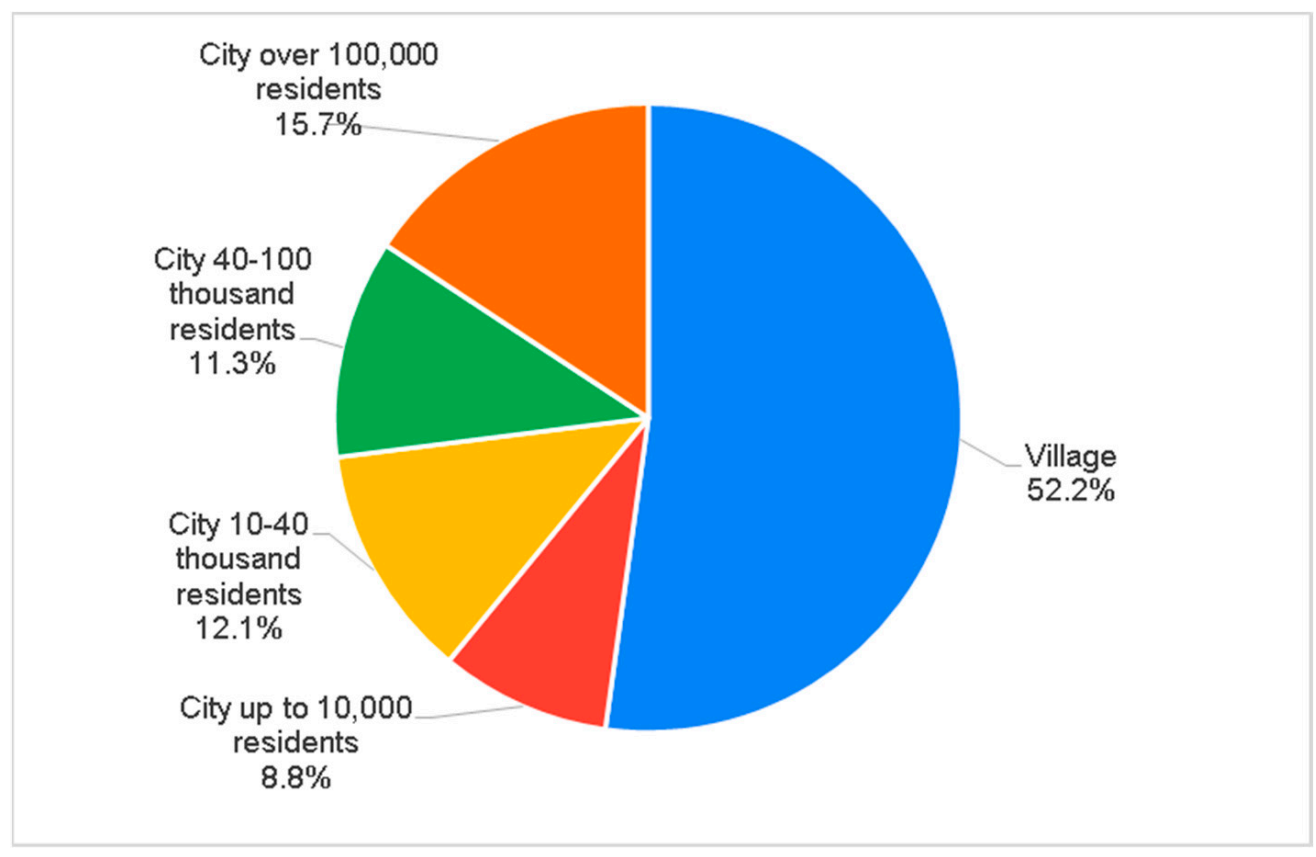

Figure 5. The structure of adult respondents by place of residence.

Figure 6 presents the structure of theses assessments used to identify attitudes and perceptions of the studied phenomena. The theses relating to the need to limit consumption and reduce $\mathrm{CO}_{2}$ emissions were highly approved by the respondents. The former was supported by $68.6 \%$ of people, while the latter was supported by $82.7 \%$. This means that the subjects were convinced of the decisive anthropogenic impact on global warming.

Concerning limiting the human population in order to protect the climate, $57.5 \%$ of respondents were against such actions. Thus, the respondents perceive contemporary problems, but do not see their solution in human depopulation. The assessment of the energy sector was dominated by responses clearly confirming its negative impact on the natural environment $(42.0 \%)$, and $62.0 \%$ of the respondents confirmed this thesis in total. This is an interesting observation as part of this sector is renewable energy, with which the respondents hope to cover the growing energy demand $(87.7 \%)$. This may mean that the respondents associate the energy sector primarily with high-emission energy sources.

Concerning the impact of nuclear power on the natural environment, there was a moderate acceptance; $37.7 \%$ of the respondents did not confirm the thesis about the negative impact of nuclear power plants on the environment. However, nearly half of the respondents $(49.5 \%)$ were against the construction of a nuclear power plant in the vicinity of their place of residence (Figure 6).

The theses aimed at identifying the ecological attitude in practical terms, and relating to the purchasing attitude, i.e., conscious and moderate consumption, were highly rated. This means that most of the respondents do not buy in advance (74.2\%), are convinced of the high quality of food produced using organic and traditional methods $(84.7 \%)$, and are able to bear slightly higher costs of organic, safe, and wholesome food. (70.9\%) (Figure 6). This means that the respondents had a formed ecological attitude.

Figure 7 shows the average ratings of theses relating to the energy sector. These data show that among the respondents there was a belief that it was possible to meet the growing energy needs with energy from renewable sources. Respondents also showed moderate concern about the negative environmental impact of the energy sector. As far as nuclear energy is concerned, the average scores were approximately 3 , which meant that there was no unambiguous opinion. On the other hand, the average assessment of the thesis supporting the construction of a nuclear power plant close to the respondents' place of residence indicated moderate skepticism. 


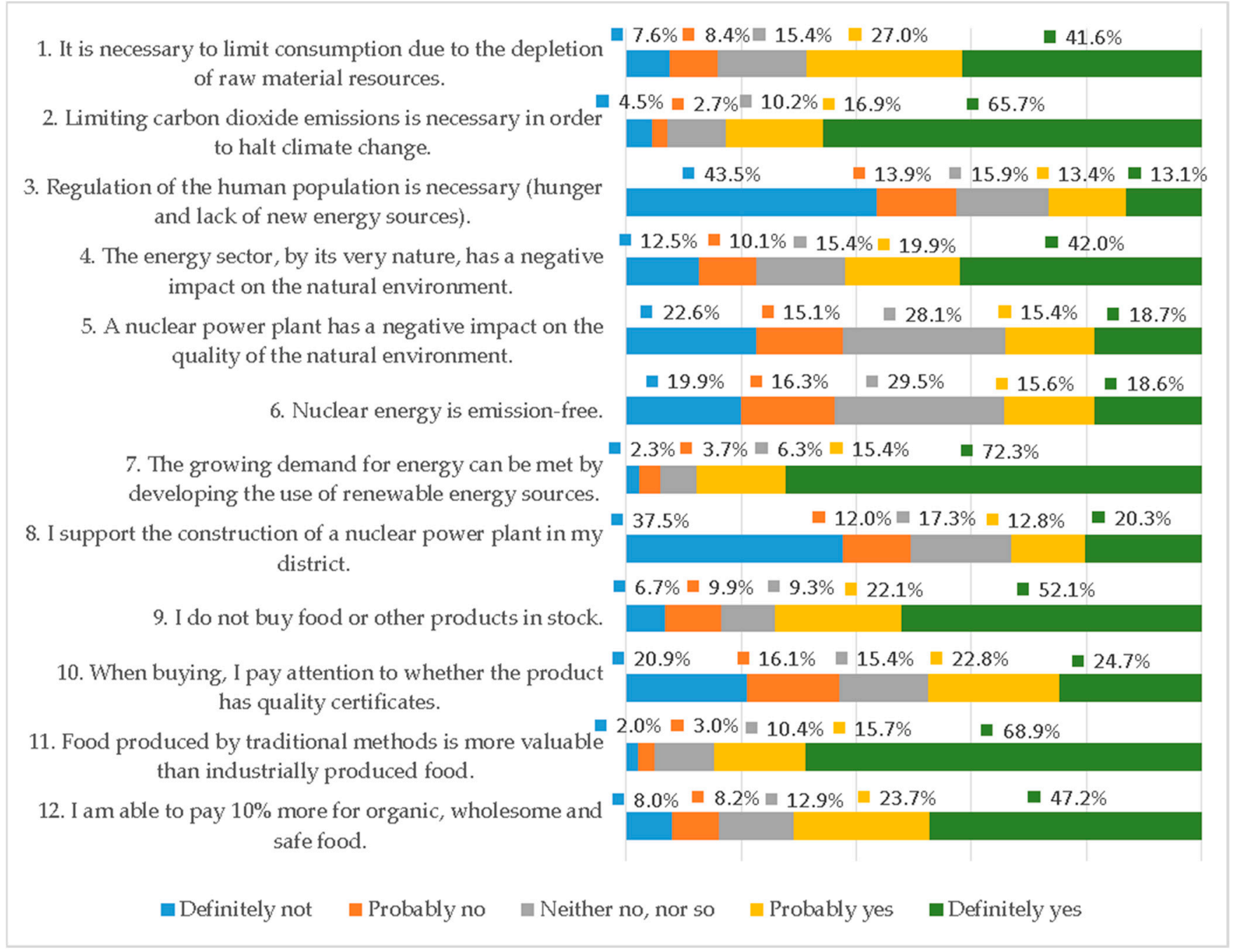

Figure 6. The structure of assessments of theses diagnosing attitudes and perception of the studied phenomena by adult respondents.

Comparing the data from Figures 6 and 7, it can be concluded that some of the respondents were afraid of nuclear power, were convinced about the negative impact of the energy sector on the environment, and had high hopes for the development of renewable energy sources. In the surveyed group, some respondents were open to nuclear energy, perceived it as emission-free, and had no concerns about the proximity of the nuclear power plant.

At the conceptualization stage, it was assumed, inter alia, that people belonging to social organizations, whose goals include care for the natural environment, have a higher level of ecological sensitivity. Therefore, it can be expected that their perception of the energy sector is different from that of other people not involved in social activities. In the studied group, $16.1 \%$ of people declared affiliation to social organizations that care about the quality of the natural environment.

Figure 8 shows a comparison of the average ratings of theses in groups of people belonging to pro-ecological social organizations, and those not belonging to such organizations, and by gender. It should be noted that the differences in the perception of the impact of the energy sector on the environment were smaller depending on the fact of social activity of people in pro-ecological organizations than the differences between people of different sexes. It can be concluded that in the studied group, the social activity of the respondents was not related to the perception of the impact of the energy sector on the 
natural environment. At the same time, the lack of such a relationship may be the result of the fact that the majority of respondents are ecologically sensitive, which is confirmed by the results presented in Figure 6.

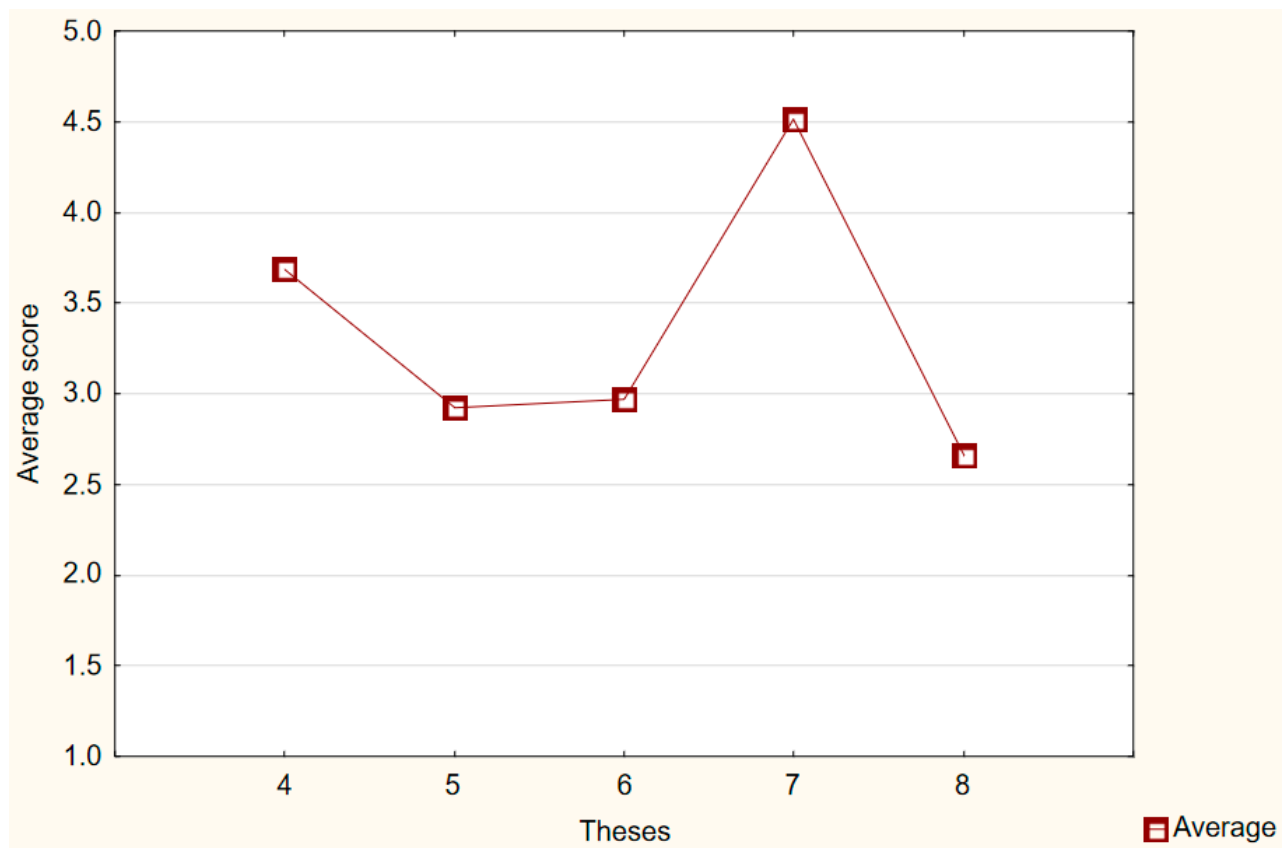

4. The energy sector, by its very nature, has a negative impact on the natural environment; 5 . A nuclear power plant has a negative impact on the quality of the natural environment; 6 . Nuclear energy is emission-free; 7. The growing demand for energy can be met by developing the use of renewable energy sources; 8 . I support the construction of a nuclear power plant in my district.

Figure 7. Average ratings of theses relating to the energy sector.

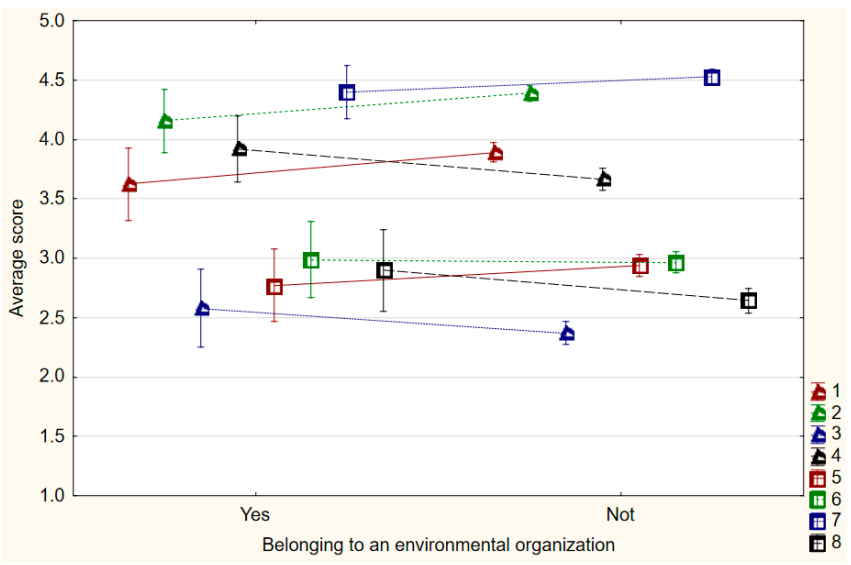

(a)

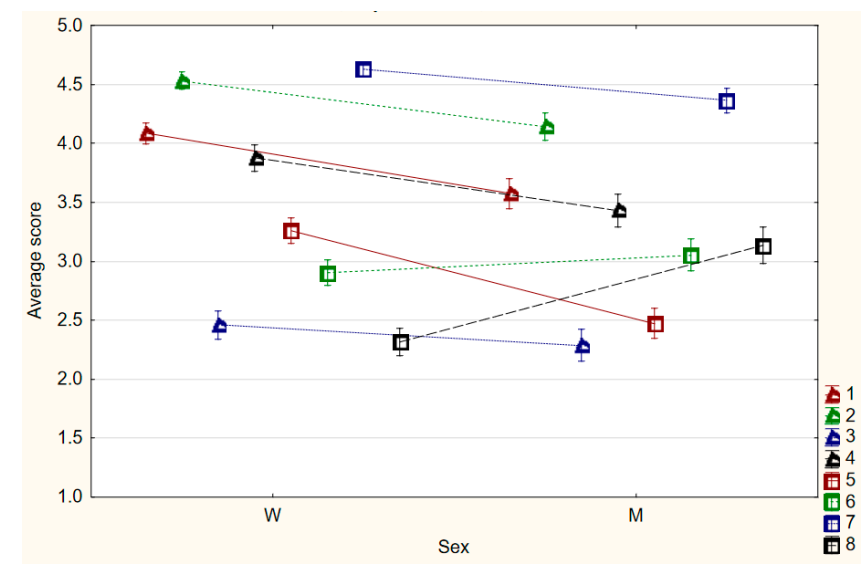

(b)

1. It is necessary to limit consumption due to the depletion of raw material resources; 2. Limiting $\mathrm{CO}_{2}$ emissions is necessary in order to halt climate change 3. Human population regulation is necessary due to the specter of overpopulation, hunger and the lack of new energy sources; 4 . The energy sector, by its very nature, has a negative impact on the natural environment; 5 . A nuclear power plant has a negative impact on the quality of the natural environment; 6 . Nuclear energy is emission-free; 7. The growing demand for energy can be met by developing the use of renewable energy sources; 8. I support the construction of a nuclear power plant in my district.

Figure 8. Average ratings of theses diagnosing the ecological attitude and the perception of the energy sector categorized due to (a) membership in pro-ecological organizations; (b) sex of respondents. 
The data presented in Figure 8 show that gender was important in the assessment of many issues. Differences can be seen regarding the need to reduce $\mathrm{CO}_{2}$ consumption and emissions. Women declared greater support for these theses than men. Women also saw more of the negative impact of the energy sector on the environment, including the negative impact of nuclear power plants. The assessment of consent to build a nuclear power plant near the respondents' place of residence was different. In this case, men showed greater acceptance of this thesis.

One of the elements of the study was an attempt to learn about the expectations and preferences of the respondents in relation to the direction of development of the energy sector. The structure of expectations regarding the direction of development of the energy sector in Poland is presented in Figure 9.

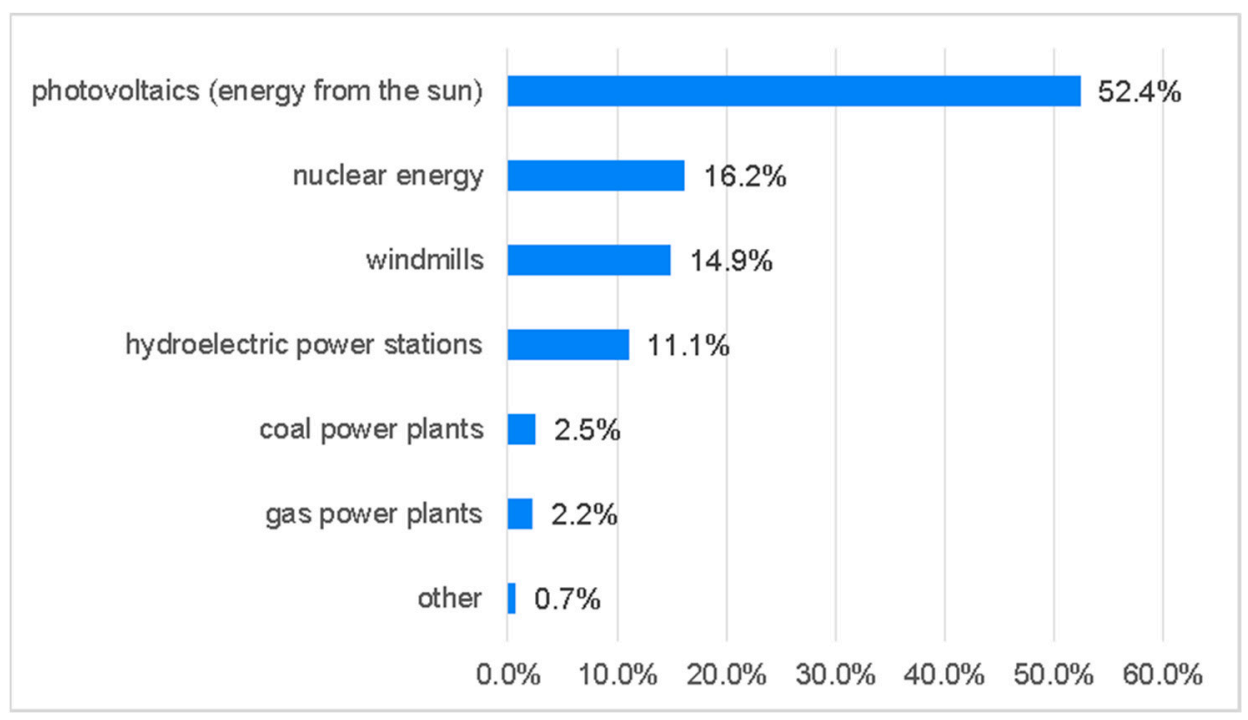

Figure 9. Respondents' expectations regarding the development of energy sources in Poland.

These data show that photovoltaic is the main expected direction of development of the energy sector (52.4\% of indications). The second largest group was nuclear power $(16.2 \%)$. Noteworthy is the low support for the development of coal and gas energy.

\section{Discussion}

As stated in the International Energy Agency's report from 2021 [15], the energy sector is responsible for about three-quarters of greenhouse gas emissions and is of key importance in limiting the effects of climate change. Reducing these emissions is to prevent further global temperature increases and halt climate change. As the report cited above shows, this will require enormous financial outlays. It is assumed that the total annual investments in the energy sector will increase to the level of 5 trillion USD (United States Dollar) by 2023, which is an additional 0.4 percentage points annually to global Gross Domestic Product (GDP). These high costs require social consensus, hence the social perception of the impact of the energy sector and social consent to undertake broad and profound changes in the current lifestyle [37].

The social perception of climate change is a fundamental issue: it can influence political decision-makers in shaping the legal order and in creating incentives and requirements for respecting the natural environment $[52,53]$. The surveyed youth expressed their concern about climate change and confirmed the necessity to undertake actions limiting its changes. Similar results were obtained in the first decade of the 21st century in the relatively wealthy US society. However, it was emphasized that the effect of reducing consumption and caring for the natural environment is greater when the public is well informed about the benefits of such activities [54]. 
The involvement of young people in activities aimed at respecting the environment and saving energy is known and largely depends on education [46,55]. Environmental education plays an important role in preventing climate change, caring for the natural environment, and transforming society towards sustainable development [56]. The surveyed youth saw the need to care for the natural environment. It showed great understanding for reducing consumption and emissions of greenhouse gases. At the same time, the quality of the local natural environment was perceived as satisfactory, and the condition of the environment was of concern, mainly at the global level. The sensitivity of young people to the problems of the quality of the natural environment is shaped by many factors. Parents [57] play an important role, but also the youth education system [58]. The results obtained show greater concern about the quality of the global environment and less concern for the local environment, and may prove that young people are highly sensitive to global problems presented in the curricula [58].

The expectations of the adolescents studied were consistent with the results obtained by other authors $[43,54]$. They mainly concerned the improvement of energy efficiency, the reduction of energy consumption, and especially the development of renewable energy.

In studies conducted in the USA, it was recommended to take into account the social perception of the costs of renewable energy in shaping the path of changes in the energy sector [59]. It is worth emphasizing that social conviction regarding specific actions, also in the area of climate protection, does not take into account all the variables. Often the economic costs are not widely realized, and social belief is the result of incomplete knowledge of the issue [60]. The respondents saw the economic aspect of the development of renewable energy. However, mainly the benefits of renewable energy sources were pointed out, above all, the improvement of air quality was emphasized. A similar, positive attitude towards renewable energy sources was identified by other authors [61-63].

The perception and acceptance of renewable energy sources is key to a successful transformation of the energy sector [61], hence the positive opinion of the respondents is a good predictor of this transformation. In the research conducted, pro-ecological attitudes and concern of adult respondents about the condition of the natural environment were associated with a positive attitude to renewable energy sources.

The belief of society about an anthropogenic impact on global warming is confirmed by numerous studies. The perception of environmental quality issues depends on many factors, both social and individual characteristics of people. The importance of ecological education and shaping pro-ecological attitudes are emphasized [54,64-68]. Similar relationships have been identified in studies conducted in southeastern Poland. However, the postulates of limiting the human population in order to stop climate change [69] were not confirmed in the conducted studies.

The respondents expressed different views on the impact of power plants on the quality of the natural environment. In the studied group, the functioning of the belief about the negative impact of nuclear power plants on the quality of the natural environment was identified. Such a stance is in contradiction with the studies of other authors who emphasize the high level of safety of nuclear power plants [70,71].

The literature emphasizes the relationship between the ecological attitude and the consumption of ecological products [72]. People with greater knowledge about the humannature relationship, characterized by an ecological attitude, noticed the need to reduce consumption and emissions of pollutants. Therefore, shaping pro-ecological attitudes and the diffusion of knowledge about the real environmental effects of obtaining energy from various sources is crucial for reliable discourse and social participation in shaping the energy transformation [73].

The research shows that among the respondents, support for the development of photovoltaic energy dominates. It is an interesting result as it proves the high ecological awareness of the respondents. The positive effects of the development of photovoltaics relate to distributed generation, which does not require investment in grid infrastructure. It is worth emphasizing that in the research area, the government program for cofinancing 
photovoltaic installations "My Electricity" enjoyed great popularity (the largest in the Podkarpackie Province) [74]. This is a successful observation because photovoltaics have great development potential, especially in the context of new solar energy conversion technologies. It is worth mentioning that in Poland, the production of highly efficient new generation cells, perovskites, has started, which have a chance to dynamize the production of solar energy $[75,76]$. Therefore, it can be expected that the society in the area studied is ready to disseminate clean energy technologies. The second most important source of energy mentioned by the respondents was nuclear energy, and the third was wind energy. This means that in the group studied the support for nuclear energy is relatively high [77].

Place of residence influences the perception of the energy sector. Depending on the industrialization of the region and the type of dominant energy source, inhabitants perceive the energy sector differently [78]. Most of the people surveyed in this study 59.6\% lived in cities; $40.4 \%$ lived in villages. There were no significant differences in the tendencies of perceiving the impact of the energy sector on the quality of the natural environment depending on the size of the place of residence.

\section{Conclusions}

The young respondents were sensitive to the problem of global warming, saw the role of man in the formation of climate change, and hoped that it could be stopped through human efforts. The vast majority of young people surveyed perceived global warming as one of the greatest problems of mankind, and the young people had the highest concerns about the condition of the natural environment from a global perspective. From the national perspective, these concerns were lower, and from the local perspective, young people were sure that their natural environment is in good condition.

In the opinion of the vast majority of the surveyed youth, the actions of the EU or the Polish state aimed at improving energy efficiency and reducing energy consumption deserve special attention. Young people did not support the development of energy based on gas and crude oil, especially the energy of hard coal and lignite. In contrast, almost half supported the development of nuclear energy and, above all, expected the development of renewable energy sources. Among young people, there was high support for theses relating to the need to conserve energy and improve energy efficiency, which may prove the high ecological awareness of the respondents.

Among the advantages of renewable energy, the young people surveyed most appreciated the improvement in air quality and the positive impact on the generally understood health protection. Among the disadvantages of renewable energy, the respondents emphasized the high costs of construction and operation of this type of energy source. There was also a strong conviction among young respondents that RES are a significant tool for reducing the negative human impact on the quality of the natural environment. It should be said that among young people, greater concern about global warming, climate change, and the quality of the environment was associated with more positive assessments of renewable energy.

The theses regarding the need to reduce consumption and reduce $\mathrm{CO}_{2}$ emissions met with great recognition among adult respondents, so respondents were convinced of the decisive, anthropogenic impact on global warming. However, regarding the claim to regulate the human population, most respondents were against it. The respondents see contemporary problems, but do not see their solution in human depopulation.

Regarding of the energy sector, responses strongly confirming its negative impact on the natural environment prevailed among the adult respondents. This is an interesting observation as part of this sector is renewable energy, with which the respondents hope to cover the growing energy demand. This may mean that the respondents associate the energy sector primarily with high-emission energy sources.

Concerning the environmental impact of nuclear power, there was moderate acceptance among the adult group of respondents. One-third of the respondents did not confirm the thesis about the negative environmental impact of nuclear power plants. However, 
nearly one-half of the respondents were against building a nuclear power plant in the vicinity of their place of residence.

The research confirms the diversity of the respondents in the perception of the impact of energy on the natural environment. Some of the respondents, with pro-ecological sensitivity, were afraid of nuclear power, were convinced about the negative impact of the energy sector on the environment, and had high hopes for the development of renewable energy sources. The second part of the respondents was open to nuclear energy, saw it as emission-free, and had no concerns about the proximity of the nuclear power plant.

The sex of the respondents was of importance in the assessment of many issues. Differences were calculated concerning the need to reduce consumption and $\mathrm{CO}_{2}$ emissions. Women declared greater support for these theses than men. Women were also more convinced of the negative impact of the energy sector on the natural environment, including the negative impact of nuclear power plants. Women showed less acceptance than men of the location of a nuclear power plant in the vicinity of their place of residence.

Among the respondents, support for the development of photovoltaic energy dominated. It is an interesting result as it proves the high ecological awareness of the respondents. The positive effects of the development of photovoltaics relate to distributed generation that does not require investment in grid infrastructure. Nuclear power was ranked second and wind power third. Therefore, the surveyed group accepts the direction of changes in the energy sector, expects the development of renewable energy and nuclear energy, and is aware of the threats related to climate change at the global level, however, especially the young group of respondents, do not identify this threat within southeastern Poland.

\section{Recapitulation}

Based on the research results presented in the article and their discussions with the literature, the following conclusions can be made:

1. The young people surveyed believe:

- Climate change is currently one of the greatest threats to humanity (but not the only one), interpreting this phenomenon primarily as a threat to the world, and to a lesser extent to Poland and the region of origin.

- Energy policy in Poland should be aimed at better use and reduction of energy consumption, and mainly towards greater use of energy based on renewable energy, limiting energy based on hard coal and lignite.

- $\quad$ RES are associated primarily with the protection of public health, a clean environment, and the country's energy security. Nuclear energy is considered the preferred direction of energy policy development in Poland-one-half of the respondents share this opinion, while the other half are against this energy.

2. The adults surveyed believe:

- They blame the energy sector for the current negative condition of the natural environment, associating it with high-emission energy sources.

- They are divided (as in the case of young people) into supporters of nuclear power, considering it to be low-emission and not harmful, and opponents of nuclear power, seeing in it a negative impact on the quality of the environment and humanity, which is largely associated with direct memory the accident of the nuclear power plant in Chernobyl in 1986.

The surveyed respondents see the impact of the energy sector on the quality of the natural environment and expect changes to reduce negative pressure. This issue requires further research, as the economic aspect in the form of electricity prices may be of significant importance for the perception of transformations in the energy sector. 
Author Contributions: Conceptualization, K.K., M.W. and A.B.; methodology, K.K. and M.W.; software, K.K., M.W. and A.B.; validation, K.K., M.W. and A.B.; formal analysis: K.K. and M.W.; compilation, K.K., M.W. and A.B.; resources, A.B., K.K. and M.W.; data processing, K.K., M.W. and A.B.; writing—original project preparation, K.K., M.W. and A.B.; writing-review and editing, K.K., A.B. and M.W.; visualization, K.K., M.W. and A.B. All authors have read and agreed to the published version of the manuscript.

Funding: These studies received no external financing.

Institutional Review Board Statement: Not applicable.

Informed Consent Statement: Not applicable.

Conflicts of Interest: The authors declare no conflict of interest.

\section{References}

1. Regulation 2018/1999-Governance of the Energy Union and Climate Action, Amending Regulations (EC) No 663/2009 and (EC) No 715/2009 of the European Parliament and of the Council, Directives 94/22/EC, 98/70/EC, 2009/31/EC, 2009/73/EC, 2010/31/EU, 2012/27/EU and 2013/30/EU of the European Parliament and of the Council, Council Directives 2009/119/EC and (EU) 2015/652 and repealing Regulation 525/2013. EU Monitor. 2018, 328, 1-77. Available online: https://www.eumonitor. eu/9353000/1/j9vvik7m1c3gyxp/vkuib7k5toxl (accessed on 15 July 2021).

2. Regulation 2019/942-EU Agency for the Cooperation of Energy Regulators. EU Monitor. 2019, 158, 22-53. Available online: https:/ /www.parlementairemonitor.nl/9353000/1/j9tvgajcor7dxyk_j9vvij5epmj1ey0/vkzda5zt2mzn (accessed on 15 July 2021).

3. Bukowski, M. Nowe Otwarcie. Polska na Drodze do Zeroemisyjnej Gospodarki (New Opening. Poland on the Road to a Zero-Emission Economy). WiseEuropa 2019, Warszawa. Available online: https://wise-europa.eu/wp-content/uploads/2019/0 3/Nowe_otwarcie_Polska_zeroemisyjna.pdf (accessed on 1 July 2021).

4. $\operatorname{COM}(2016) 860$-Communication. Clean Energy for All Europeans. 2016. Available online: https://ec.europa.eu/energy/sites/ ener/files/documents/com_860_final.pdf (accessed on 15 July 2021).

5. Directive 2018/2001-Promotion of the Use of Energy from Renewable Sources. EU Monitor. 2018, 328, 82-209. Available online: https:/ / www.eumonitor.eu/9353000/1/j9vvik7m1c3gyxp/vkuib7k2iyxj (accessed on 15 July 2021).

6. Strategic Plan for 2020-2025. Centre for International Governance Innovation. 2019. Available online: https://www.cigionline.org/ sites/default/files/documents/Strategic_Plan-2020-web2.pdf (accessed on 9 April 2021).

7. Paris Agreement. United Nations. 2015. Available online: https://unfccc.int/sites/default/files/english_paris_agreement.pdf (accessed on 9 July 2021).

8. Katowice Rulebook. Getting Ready for the Implementation Era. United Nations Climate Change Conference COP24, Katowice 2018. Ministry of the Environment of the Republic of Poland and Bureau of the COP24 Presidency. Available online: https: / / cop24.gov.pl/fileadmin/DEKLARACJE/Katowice_Ruleboo_E-BOOK_mini.pdf (accessed on 15 July 2021).

9. Regulation 2019/943-Internal market for electricity. EU Monitor 2019, 158, 54-124. Available online: https: / www.eumonitor. eu/9353000/1/j9vvik7m1c3gyxp/vkzda5zupszo (accessed on 15 July 2021).

10. Regulation 2019/941-Risk-Preparedness in the Electricity Sector and Repealing Directive 2005/89/EC. EU Monitor 2019, 158, 1-21. Available online: https:/ / www.eumonitor.eu/9353000/1/j9vvik7m1c3gyxp/vkzda5zrezzm (accessed on 15 July 2021).

11. Decision 2019/504-Amending Directive 2012/27/EU on Energy Efficiency and Regulation (EU) 2018/1999 on the Governance of the Energy Union and Climate Action, by Reason of the Withdrawal of the United Kingdom from the Union. EU Monitor 2019, 851, 66-68. Available online: https://www.eumonitor.eu/9353000/1/j9vvik7m1c3gyxp/vkx67hmd9ryt (accessed on 15 July 2021).

12. Rackiewicz, I. Raport o Stanie Polskich Miast. In Niskoemisyjność i Efektywność Energetyczna; Report on the Condition of Polish Cities; Low Emission and Energy Efficiency; Instytut Rozwoju Miast: Kraków, Poland, 2017; Available online: http:/ / obserwatorium.miasta.pl/wp-content/uploads/2017/08/Raport_Niskoemisyjno\%C5\%9B\%C4\%87_i_efektywno\%C5 \%9B\%C4\%87_energetyczna_obserwatorium_OPM_IRM_Bartocha_Rackiewicz.pdf (accessed on 15 July 2021).

13. Tilburg, X.; Fearnehough, H. The Energy Transition after Covid-19. Perspectives on Green Recovery and NDC Ambition Raising. Report New Climate Institute. 2021. Available online: https://ambitiontoaction.net/wp-content/uploads/2021/02/Energy-sectorafter-COVID19_A2A-policy-briefing.pdf (accessed on 17 July 2021).

14. Energy Policy of Poland until 2040; Ministry of Climate and Environment: Warsaw, Poland, 2021. Available online: https: / / www.gov.pl/attachment/376a6254-2b6d-4406-a3a5-a0435d18be0f (accessed on 15 July 2021).

15. Net Zero by 2050 A Roadmap for the Global Energy Sector. International Energy Agency. 2021. Available online: https: / / www.iea.org/reports/net-zero-by-2050 (accessed on 21 July 2021).

16. Działania UE w Dziedzinie Klimatu i Europejski Zielony Ład (EU Climate Action and the European Green Deal). 2020. Available online: https:/ / ec.europa.eu/clima/policies/eu-climate-action_pl (accessed on 21 July 2021). 
17. Annex 1 to the Energy Policy of Poland until 2040. In Analysis and Evaluation of Environmental Protection Objectives at the International, Community and National Level, Relevant to the Pep2040 Project's Point of View; Ministry of Climate and Environment: Warsaw, Poland, 2021. Available online: https://www.gov.pl/attachment/143050ec-521e-4815-9481-ce842e80985a (accessed on 15 July 2021).

18. Annex 2 to the Energy Policy of Poland until 2040. Detailed Analysis of Environmental impact of Projects That May Always and Potentially Affect the Environment; Ministry of Climate and Environment: Warsaw, Poland, 2021. Available online: https: / / www.gov.pl/attachment/579af18e-634e-4670-a3cb-28e2a30e0f76 (accessed on 15 July 2021).

19. Resolution Adopted by the General Assembly on 25 September 2015. 70/1. We Are Transforming Our World: The 2030. Agenda for Sustainable Development. United Nations, Distr.: General. A/RES/70/1. 2015. Available online: https://www.un.org/en/ development/desa/population/migration/generalassembly/docs/globalcompact/A_RES_70_1_E.pdf (accessed on 20 July 2021).

20. Report of the United Nations Conference on Environment and Development, Rio de Janeiro, 3-14 June 1992, Volume I, Resolutions Adopted by the Conference. United Nations Publication, Sales No. E.93.I.8 and Corrigendum, Resolution 1, Annex I. Available online: https:/ / www.un.org/esa/dsd/agenda21/Agenda\%2021.pdf (accessed on 20 July 2021).

21. Report of the International Conference on Population and Development, Cairo, 5-13 September 1994. United Nations Publication, Sales No. E.95.XIII.18, Chap. I, Resolution 1, Annex. Available online: https://www.un.org/development/desa/pd/sites/www. un.org.development.desa.pd/files/icpd_en.pdf (accessed on 20 July 2021).

22. Report of the Fourth World Conference on Women, Beijing, 4-15 September 1995. United Nations Publication, Sales No. E.96.IV.13, Chap. I, Resolution 1, Annex II. Available online: https:/ / www.un.org/womenwatch/daw/beijing/pdf/Beijing\%20full\%20 report\%20E.pdf (accessed on 20 July 2021).

23. GUS (Central Statistical Office). 2020. Available online: https://stat.gov.pl/ (accessed on 20 July 2021).

24. The 2030 Climate Target Plan, Communication from The Commission to The European Parliament, The Council, The European Economic and Social Committee and The Committee of The Regions, Stepping up Europe's 2030 Climate Ambition Investing in a Climate-Neutral Future for the Benefit of Our People. COM/2020/562 final. Available online: https:/ / eur-lex.europa.eu/legalcontent/EN/TXT/PDF/?uri=CELEX:52020DC0562\&from=EN (accessed on 20 July 2021).

25. Krajowy Plan na Rzecz Energii i Klimatu na lata 2021-2030 (Polish Plan for Energy and Climate for 2021-2030); Ministerstwo Aktywów Państwowych: Warszawa, Poland, 2019. Available online: https://www.gov.pl/attachment/df8c4c37-808c-44ff-9278-676fb9 4add88 (accessed on 20 July 2021).

26. Annex 2 to Krajowy Plan na Rzecz Energii i Klimatu na Lata 2021-2030 (Polish Plan for Energy and Climate for 2021-2030); Ministerstwo Aktywów Państwowych: Warszawa, Poland, 2019. Available online: https://www.gov.pl/attachment/a8db078d-535b-4b1bbfe5-bda64df73778 (accessed on 20 July 2021).

27. Narodowy Program Rozwoju Gospodarki Niskoemisyjnej (Polish Low-Carbon Economy Development Program); Ministerstwo Gospodarki: Warszawa, Poland, 2015. Available online: https://www.cire.pl/pliki/1/2018/nprgn_konsultacje_2.pdf (accessed on 24 July 2021).

28. The World Bank Data. Climate Change. 2019. Available online: https:// data.worldbank.org/topic/19 (accessed on 24 July 2021).

29. WMO Provisional Statement on the State of the Global Climate in 2019. Available online: https://library.wmo.int/doc_num. php?explnum_id=10108 (accessed on 24 July 2021).

30. Weather, Climate E Catastrophe Insight; Annual Report; AON Chicago. 2019. Available online: http://thoughtleadership.aon.com/ Documents /20200122-if-natcat2020.pdf?utm_source=ceros\&utm_medium=storypage\&utm_campaign=natcat20 (accessed on 24 July 2021).

31. Ritchie, H. Cars, Planes, Trains: Where do CO2 Emissions from Transport Come From? Our World in Data. 2020. Available online: https: / / ourworldindata.org/co2-emissions-from-transport (accessed on 24 July 2021).

32. Annual European Union Greenhouse Gas Inventory 1990-2019 and Inventory Report 2021; European Environment Agency (EEA) Kopenhaga. 2021, p. 981. Available online: https:/ /www.eea.europa.eu/publications/annual-european-union-greenhouse-gasinventory-2021 (accessed on 24 July 2021).

33. IPCC Special Report 2018. Available online: https://www.ipcc.ch/site/assets/uploads/sites/2/2019/05/SR15_Chapter1_Low_ Res.pdf (accessed on 9 April 2021).

34. Steffen, W.; Rockström, J.; Richardson, K.; Lenton, T.M.; Folke, C.; Liverman, D.; Summerhayes, C.P.; Barnosky, A.D.; Cornell, S.E.; Crucifix, M.; et al. Trajectories of the Earth System in the Anthropocene. Proc. Natl. Acad. Sci. USA 2018, 115, 8252-8259. [CrossRef] [PubMed]

35. Luboińska, U. Emisja Gazów Cieplarnianych. Wybrane Zagadnienia Dotyczace Emisji $\mathrm{CO}_{2}$ w Polsce (Greenhouse Gas Emissions. Selected issues concerning $\mathrm{CO}_{2}$ emissions in Poland); Kancelaria Senatu: Warszawa, Poland, 2020. Available online: https://www.senat.gov. $\mathrm{pl} / \mathrm{gfx} / \mathrm{senat} / \mathrm{pl} /$ senatopracowania/192/plik/ot-683.pdf (accessed on 24 July 2021).

36. Pińskwar, I.; Choryński, A.; Kundzewicz, Z.W. Severe Drought in the Spring of 2020 in Poland-More of the Same? Agronomy 2020, 10, 1646. [CrossRef]

37. Lambert, J.G.; Hall, C.A.S.; Balogh, S.; Gupta, A.; Arnold, M. Energy, EROI and quality of life. Energy Policy 2014, 64, 153-167. [CrossRef]

38. Roser, M.; Ortiz-Ospina, E. Global Extreme Poverty. Our World in Data. 2019. Available online: https://ourworldindata.org/ extreme-poverty (accessed on 24 July 2021). 
39. IEA. International Energy Agency. 2020. Available online: https:/ / www.iea.org (accessed on 15 May 2021).

40. Ritchie, H.; Roser, M. Emissions by Sector. Our World in Data. 2016. Available online: https://ourworldindata.org/emissions-bysector (accessed on 24 July 2021).

41. FS-UNEP/BNEF, Global Trends in Renewable Energy Investment. Bloomberg NEF. 2020. Available online: https:/ /www.fsunepcentre.org/wp-content/uploads/2020/06/GTR_2020.pdf (accessed on 12 April 2021).

42. Adedoyin, F.F.; Gumede, M.I.; Bekun, F.V.; Etokakpan, M.U.; Balsalobre-lorente, D. Modelling coal rent, economic growth and $\mathrm{CO}_{2}$ emissions: Does regulatory quality matter in BRICS economies? Science 2020, 710, 136284. [CrossRef]

43. Cebrián, G.; Junyent, M.; Mulà, I. Competencies in Education for Sustainable Development: Emerging Teaching and Research Developments. Sustainability 2020, 12, 579. [CrossRef]

44. Friedlingstein, P.; O'Sullivan, M.; Jones, M.W.; Andrew, R.M.; Hauck, J.; Olsen, A.; Peters, G.P.; Peters, W.; Pongratz, J.; Sitch, S.; et al. Global Carbon Budget 2020. Earth Syst. Sci. Data 2020, 12, 3269-3340. [CrossRef]

45. Söderbaum, P. Positional Analysis: A. Multidimensional and Democracy-Oriented Approach to Decision-Making and Sustainability. Sustainability 2020, 12, 5555. [CrossRef]

46. Ardoin, N.M.; Bowers, A.W. Estelle Gaillard, Environmental education outcomes for conservation: A systematic review. Biol. Conserv. 2020, 241, 108224. [CrossRef]

47. Agbede, E.A.; Bani, Y.; Azman-Saini, W.; Naseem, N.A.M. The impact of energy consumption on environmental quality: Empirical evidence from the MINT countries. Environ. Sci. Pollut. Res. 2021, 1-20. [CrossRef]

48. Rozkrut, D. Statistical Yearbook of Forestry. Statistics Poland: Warsaw, Poland, 2019. Available online: https://stat.gov.pl/ download/gfx/portalinformacyjny/pl/defaultaktualnosci/5515/13/2/1/rocznik_statystyczny_lesnictwa_2019.pdf (accessed on 10 June 2021).

49. Synówka-Bejenka, E. Potencjał Turystyczny Województw Polski (Tourist Potential of Polish Voivodships). Wiadomości Stat. 2017, 7 , 78-92. Available online: http://bazekon.icm.edu.pl/bazekon/element/bwmeta1.element.ekon-element-000171484584 (accessed on 10 June 2021).

50. Chyung, S.Y.; Roberts, K.; Swanson, I.; Hankinson, A. Evidence-Based Survey Design: The Use of a Midpoint on the Likert Scale. Perform. Improv. 2017, 56, 15-23. [CrossRef]

51. Aczel, A.D. Statystyka $w$ Zarzadzaniu; Original: Aczel, A.D. Complete Business, Statistics, Seventh Edition, McGraw=Hill Irwin Companies, New York, 2009; Wydawnictwo Naukowe PWN Warszawa, 2018. Available online: https://ksiegarnia.pwn.pl/ Statystyka-wzarzadzaniu,731934758, p.html (accessed on 10 June 2021).

52. Antronico, L.; Coscarelli, R.; De Pascale, F.; Di Matteo, D. Climate Change and Social Perception: A Case Study in Southern Italy. Sustainability 2020, 12, 6985. [CrossRef]

53. Moore, F.C.; Obradovich, N.; Lehner, F.; Baylis, P. Rapidly declining remarkability of temperature anomalies may obscure public perception of climate change. Proc. Natl. Acad. Sci. USA 2019, 116, 4905-4910. [CrossRef]

54. Semenza, J.C.; Hall, D.E.; Wilson, D.J.; Bontempo, B.D.; Sailor, D.J.; George, L.A. Public Perception of Climate Change: Voluntary Mitigation and Barriers to Behavior Change. Am. J. Prev. Med. 2008, 35, 479-487. [CrossRef] [PubMed]

55. Blasch, J.; Filippini, M.; Kumar, N. Boundedly rational consumers, energy and investment literacy, and the display of information on household appliances. Resour. Energy Econ. 2019, 56, 39-58. [CrossRef]

56. Velasco-Martínez, L.-C.; Martín-Jaime, J.-J.; Estrada-Vidal, L.-I.; Tójar-Hurtado, J.-C. Environmental Education to Change the Consumption Model and Curb Climate Change. Sustainability 2020, 12, 7475. [CrossRef]

57. Grønhøj, A.; Thøgersen, J. Why young people do things for the environment: The role of parenting for adolescents' motivation to engage in pro-environmental behaviour. J. Environ. Psychol. 2017, 54, 11-19. [CrossRef]

58. Ballard, H.L.; Dixon, C.G.H.; Harris, E.M. Youth-focused citizen science: Examining the role of environmental science learning and agency for conservation. Biol. Conserv. 2017, 208, 65-75. [CrossRef]

59. Bayulgen, O.; Benegal, S. Green Priorities: How economic frames affect perceptions of renewable energy in the United States. Energy Res. Soc. Sci. 2019, 47, 28-36. [CrossRef]

60. Tcvetkov, P. Climate Policy Imbalance in the Energy Sector: Time to Focus on the Value of $\mathrm{CO}_{2}$ Utilization. Energies 2021, 14, 411. [CrossRef]

61. Sütterlin, B.; Siegrist, M. Public acceptance of renewable energy technologies from an abstract versus concrete perspective and the positive imagery of solar power. Energy Policy 2017, 106, 356-366. [CrossRef]

62. Ntanos, S.; Kyriakopoulos, G.; Chalikias, M.; Arabatzis, G.; Skordoulis, M. Public Perceptions and Willingness to Pay for Renewable Energy: A Case Study from Greece. Sustainability 2018, 10, 687. [CrossRef]

63. Caldés, N.; Del Río, P.; Lechón, Y.; Gerbeti, A. Renewable Energy Cooperation in Europe: What Next? Drivers and Barriers to the Use of Cooperation Mechanisms. Energies 2019, 12, 70. [CrossRef]

64. Capstick, S.B. Public Understanding of Climate Change as a Social Dilemma. Sustainability 2013, 5, 3484-3501. [CrossRef]

65. Kais, S.M.; Islam, M.S. Perception of Climate Change in Shrimp-Farming Communities in Bangladesh: A Critical Assessment. Int. J. Environ. Res. Public Health 2019, 16, 672. [CrossRef]

66. Yilmaz, V.; Can, Y. Impact of knowledge, concern and awareness about global warming and global climatic change on environmental behavior. Environ. Dev. Sustain. 2020, 22, 6245-6260. [CrossRef]

67. Poortvliet, P.M.; Niles, M.T.; Veraart, J.A.; Werners, S.E.; Korporaal, F.C.; Mulder, B.C. Communicating Climate Change Risk: A Content Analysis of IPCC's Summary for Policymakers. Sustainability 2020, 12, 4861. [CrossRef] 
68. Sierra-Barón, W.; Navarro, O.; Amézquita Naranjo, D.K.; Teres Sierra, E.D.; Narváez González, C.M. Beliefs about Climate Change and Their Relationship with Environmental Beliefs and Sustainable Behavior: A View from Rural Communities. Sustainability 2021, 13, 5326. [CrossRef]

69. Ganivet, E. Growth in human population and consumption both need to be addressed to reach an ecologically sustainable future. Environ. Dev. Sustain. 2020, 22, 4979-4998. [CrossRef]

70. Lomonaco, G.; Mainardi, E.; Marková, T.; Mazzini, G. Approaching Nuclear Safety Culture in Fission and Fusion Technology. Appl. Sci. 2021, 11, 4511. [CrossRef]

71. Badia, E.; Navajas, J.; Losilla, J.-M. Safety Culture in the Spanish Nuclear Power Plants through the Prism of High Reliability Organization, Resilience and Conflicting Objectives Theories. Appl. Sci. 2021, 11, 345. [CrossRef]

72. Testa, F.; Pretner, G.; Iovino, R.; Bianchi, G.; Tessitore, S.; Iraldo, F. Drivers to green consumption: A systematic review. Environ. Dev. Sustain. 2021, 23, 4826-4880. [CrossRef]

73. Doukas, H.; Nikas, A.; Stamtsis, G.; Tsipouridis, I. The Green Versus Green Trap and a Way Forward. Energies 2020, $13,5473$. [CrossRef]

74. Raport. Rynek Fotowoltaiki w Polsce. Instytutu Energetyki Odnawialnej. Warszawa. 2021. Available online: https://ieo.pl/pl/ raport-pv-2021 (accessed on 8 June 2021).

75. Website. SAULE Technologies. Available online: https:/ / sauletech.com (accessed on 25 June 2021).

76. Babu, V.; Pineda, R.F.; Ahmad, T.; Alvarez, A.O.; Castriotta, L.A.; Di Carlo, A.; Fabregati, F.; Wojciechowski, K. Improved Stability of Inverted and Flexible Perovskite Solar Cells with Carbon Electrode. ACS Appl. Energy Mater. 2020, 3, 5126-5134. [CrossRef]

77. Zawalińska, K.; Kinnunen, J.; Gradziuk, P.; Celińska-Janowicz, D. To Whom Should We Grant a Power Plant? Economic Effects of Investment in Nuclear Energy in Poland. Energies 2020, 13, 2687. [CrossRef]

78. Crowe, J.A.; Li, R. Is the just transition socially accepted? Energy history, place, and support for coal and solar in Illinois, Texas, and Vermont. Energy Res. Soc. Sci. 2020, 59, 101309. [CrossRef] 